\title{
The Crvenka loess-paleosol sequence: A record of continuous grassland domination in the southern Carpathian Basin during the Late Pleistocene
}

\author{
Slobodan B. Markovića ${ }^{\mathrm{ab}, *}$, Pál Sümegi ${ }^{\mathrm{c}}$, Thomas Stevens ${ }^{\mathrm{d}, \mathrm{a}}$, Randall J. Schaetzl ${ }^{\mathrm{e}}$, Igor Obreht ${ }^{\mathrm{f}, \mathrm{g}}$, \\ Wei Chu ${ }^{\mathrm{h}}$, Björn Buggle ${ }^{\mathrm{i}}$, Michael Zech ${ }^{\mathrm{j}}$, Roland Zech ${ }^{\mathrm{k}}$, Christian Zeeden ${ }^{\mathrm{g}, 1}$, Milivoj B. Gavrilov ${ }^{\mathrm{a}}$, \\ Zoran Perića ${ }^{\text {, Zorica Svirčev }}{ }^{\mathrm{m}}$, Frank Lehmkuhl ${ }^{\mathrm{g}}$ \\ ${ }^{\text {a } C h a i r ~ o f ~ P h y s i c a l ~ G e o g r a p h y, ~ F a c u l t y ~ o f ~ S c i e n c e s, ~ U n i v e r s i t y ~ o f ~ N o v i ~ S a d, ~ T r g ~ D o s i t e j a ~ O b r a d o v i c ́ a ~ 3, ~} 21000$ Novi Sad, Serbia \\ ${ }^{\mathrm{b}}$ Serbian Academy of Sciences and Arts, Kneza Miloša 35, 11000 Belgrade, Serbia \\ ${ }^{\mathrm{c}}$ Department of Geology and Paleontology, University of Szeged, Egyetem u. 2-6, H-6722 Szeged, Hungary \\ d Department of Earth Sciences, Uppsala University, Villavägen 16, 75236 Uppsala, Sweden \\ e Department of Geography, Environment, and Spatial Sciences, Michigan State University, 128 Geography Building, East Lansing, MI 48824, USA \\ ${ }^{f}$ Organic Geochemistry Group, MARUM-Center for Marine Environmental Sciences and Department of Geosciences, University of Bremen, D-28359 Bremen, Germany \\ ${ }^{g}$ Department of Geography, RWTH Aachen University, Templergraben 55, D-52056 Aachen, Germany \\ ${ }^{\mathrm{h}}$ Institute of Prehistoric Archaeology, University of Cologne, Bernhard-Feilchelfeld-Str.11, 50969 Cologne, Germany \\ ${ }^{\mathrm{i}}$ ETH Zürich, Geologisches Institut, Sonneggstrasse 5, 8092 Zürich, Switzerland \\ ${ }^{j}$ Department of Physical Geography, Technical University of Dresden, Helmholtzstr. 10, D-01069 Dresden, Germany \\ ${ }^{\mathrm{k}}$ Geological Institute, ETH Zurich, Switzerland \\ ${ }^{1}$ IMCCE, Observatoire de Paris, PSL Research University, CNRS, Sorbonne Universités, UPMC Univ Paris 06, Univ Lille, 75014 Paris, France \\ ${ }^{m}$ LAPER, Faculty of Sciences, University of Novi Sad, Trg Dositeja Obradovića 3, 21000 Novi Sad, Serbia
}

\section{A R T I C L E I N F O}

\section{Keywords:}

Grassland

Mollusks

Loess

Biomarkers

Serbia

\begin{abstract}
A B S T R A C T
In this study, we compare two independent paleoenvironmental proxies for a loess sequence in northern Serbia, in the southern Carpathian Basin: novel $n$-alkane biomarkers and traditional land snail assemblages. Both are associated with other, more widely used proxy data for loess sections, such as environmental magnetism, grain size, and geochemical indices. Together, these paleoenvironmental proxy records provide evidence for the continued dominance of grasslands during the Late Pleistocene in the Southern Carpathian Basin. It is contrary to other European loess provinces, which are characterized by high diversity of Late Pleistocene environments (ranging from tundra-like to deciduous forest habitats). These findings highlight the southeastern part of Carpathian Basin as an important, but still insufficiently investigated, biogeographical refugium, and biodiversity preservation zone. The reason for this is a mostly stable paleoclimate for much of the Late Pleistocene.
\end{abstract}

\section{Introduction}

The thick loess-paleosol sequences (LPSs) of the Vojvodina region (Serbia) in the southeastern part of the Carpathian Basin contain detailed records of Middle and Late Pleistocene climatic and environmental conditions. Aeolian silt (loess) accumulation in Vojvodina began in the late Early Pleistocene or earlier, providing a potentially long record of environmental conditions (Marković et al., 2011). Due to high aeolian sediment accumulation rates, the Late Pleistocene LPS preserve an especially detailed and quasi-continuous record of climatic and environmental changes in this region (Marković et al., 2008; Fuchs et al., 2008). The majority of previous investigations in southeastern part of Carpathian Basin have been to focused on loess of the Srem and Titel loess plateaus (Kostić and Protić, 2000; Marković et al., 2005, 2006, 2009, 2012; Antoine et al., 2009; Bokhorst et al., 2009; Schmidt et al., 2010; Újvári et al., 2010; Murray et al., 2014; Bjelajac et al., 2016) (Fig. 1). However, a more complete understanding of the environmental dynamics across the entire basin necessitates the investigation of other loess deposits between these more intensively studied areas.

Despite a long tradition of loess research on the Bačka Loess Plateau (BLP) (e.g. Halaváts, 1895, 1897; Marković-Marjanović, 1964, 1966, 1967; Molnár and Krolopp, 1978) only a few recent studies report results from the plateau area, which lies between the parallel flows of the Danube and Tisa rivers in northern Serbia and southern Hungary (Sümegi and Krolopp, 2002; Marković et al., 2008; Bokhorst et al., 2011; Sümegi et al., 2013). Recently, the Crvenka section on the

\footnotetext{
* Corresponding author at: Chair of Physical Geography, Faculty of Sciences, University of Novi Sad, Trg Dositeja Obradovića 3, 21000 Novi Sad, Serbia.

E-mail address: slobodan.markovic@dgt.uns.ac.rs (S.B. Marković).
} 


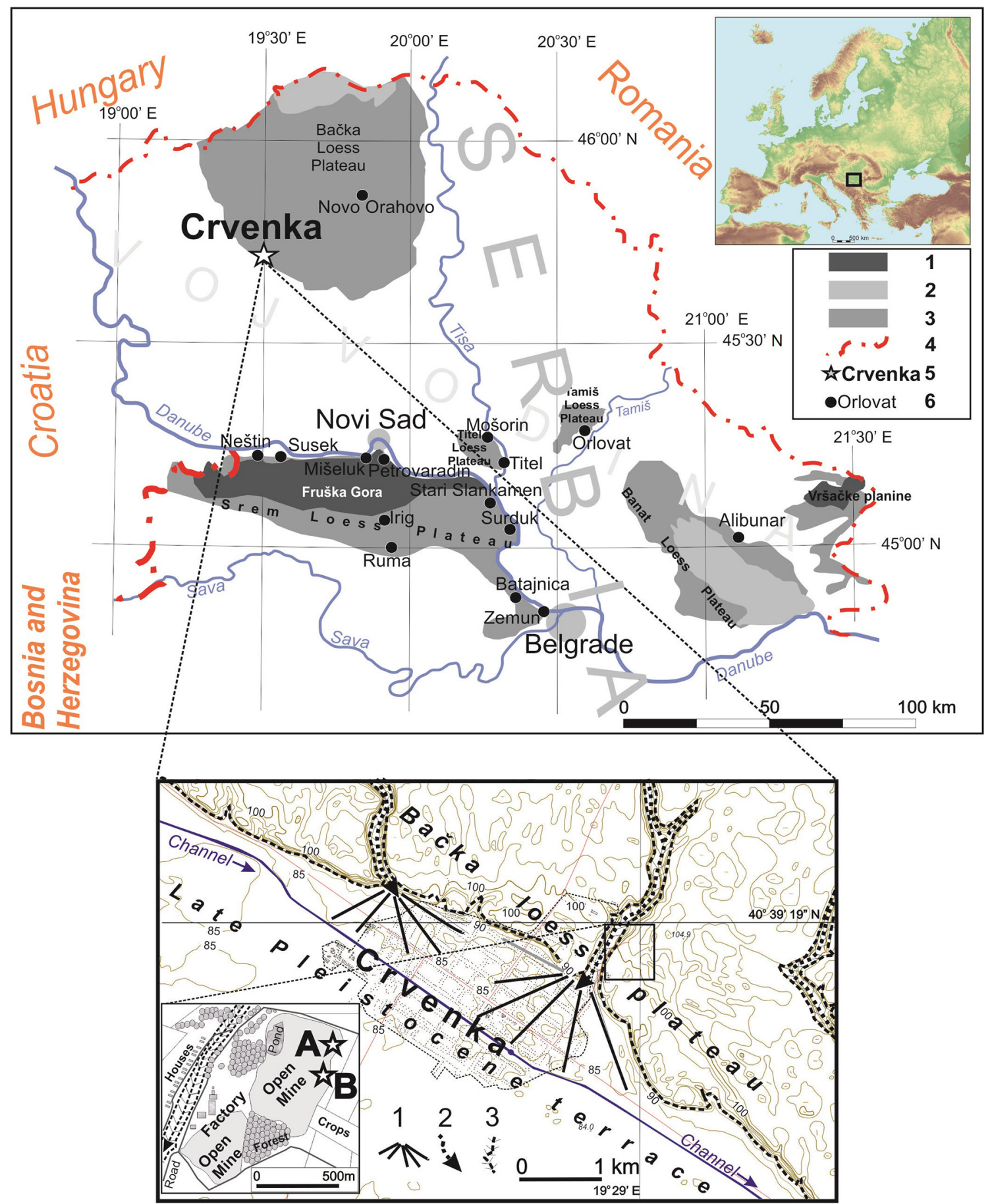

Fig. 1. Study area. A) Geographic location of the Crvenka brickyard exposure and other relevant sites in the Vojvodinian loess area. Legend: 1. Loess plateau; 2. sandy area; 3 . mountain; 4. state border; 5 . Crvenka site; 6 . main loess sections.

B) Basic geomorphologic map of the study site. Inset: aerial photograph of the site. The investigated exposures are denoted by letters A and B on the photograph (Stevens et al., 2011, modified).

Legend: 1. Alluvial fan; 2. gullies; 3. loess cliffs and slopes.

southern edge of BLP was recognized as a promising site for the reconstruction of Late Pleistocene climatic and environmental evolution in the region (Zech et al., 2009, 2013; Stevens et al., 2011; Häggi et al., 2014; Sümegi et al., 2016).

Our study takes advantage of this setting by utilizing several independent methods of characterizing the environmental history of this region. We employed traditional approaches toward loess research (magnetic properties, grain size distribution, and malacology) with a more recently developed isotopic and biomarker approach. Our results confirm previously reported hypotheses of reduced Late Pleistocene environmental fluctuations in the Middle Danube (Carpathian) Basin (e.g. Marković et al., 2006, 2015; Hatté et al., 2013), when compared to those seen in other European loess provinces, and from other terrestrial records (Rousseau, 2001; Rousseau et al., 2007; Wohlfarth et al., 2008; Jary, 2011; Seelos et al., 2009; Sirocko et al., 2016). These studies point to abrupt cooling intervals, potentially associated with large-scale iceberg-rafting events known as Heinrich events (Heinrich, 1988), as well as with sudden shifts from cold to more mild climatic conditions 
potentially linked to Dansgaard/Oeschger cycles recorded in the North Atlantic Ocean region (e.g. Bond et al., 1993; Dansgaard et al., 1993). Thus, we propose that the southeastern part of the Carpathian Basin may be regarded as an important but still insufficiently investigated biogeographical refugium for biodiversity preservation, where the paleoclimate may have been stable for much of the Late Pleistocene.

\section{Material and methods}

Our study site is focused on the Crvenka brickyard $\left(45^{\circ} 39.75^{\prime} \mathrm{N}\right.$, $19^{\circ} 28.77^{\prime} \mathrm{E}$ ), located on the southwestern edge of the BLP $\sim 150 \mathrm{~km}$ northwest of Belgrade, Serbia. Here, a 11-m-thick loess exposure provides a unique opportunity to investigate Late Pleistocene environmental dynamics.

In this study, we investigated two subsections, Crvenka $\mathrm{A}$ and Crvenka B, that are ca. $150 \mathrm{~m}$ apart, along the 500-m-long loess profile of the active and inaccessible (due to mining activities) main Crvenka brickyard. Due to the nearly horizontal position of the loess-paleosol sequences, inter-profile correlations at the brickyard are straightforward (Fig. 1).

In 2007, investigations began at section A (Marković et al., 2008; Zech et al., 2009, 2013; Stevens et al., 2011). The section was carefully cleaned, described, and sampled for grain size distribution at $5 \mathrm{~cm}$ intervals (Stevens et al., 2011), and samples were taken for malacological and $n$-alkane biomarkers and $\mathrm{C}$ and $\mathrm{N}$ isotope analyses every $25 \mathrm{~cm}$. Details of sample preparation and laboratory measurements related to geochemical and $n$-alkane biomarker analyses are described in previous studies of Zech et al. (2009, 2013), and here are briefly presented in Supplementary material. This section has subsequently been partly disturbed during raw material exploitation. Thus, we pursued an additional investigation at Section B in 2009, where samples were taken at $\sim 25 \mathrm{~cm}$ intervals for rock magnetic measurements, grain size, total organic carbon (TOC), $\delta^{13} \mathrm{C}, \delta^{15} \mathrm{~N}$, and $n$-alkane biomarkers (Zech et al., 2013; Häggi et al., 2014).
Low field magnetic susceptibility $(\chi)$ was measured at Section A at 5 -cm intervals in the field, using a portable Bartington MS2 susceptibility meter. At each interval, ten independent readings were taken and averaged (Stevens et al., 2011). The $\chi$ and other rock magnetic indices were measured at the University of Bayreuth on a MAGNON Susceptibility Bridge (MAGNON, Dassel, Germany) at AC-fields of $300 \mathrm{~A} / \mathrm{m}$ at $300 \mathrm{~Hz}$ (Zech et al., 2013).

Grain-size analyses were determined using different methodological approaches. The main fractions at section A were assessed using combined sieving and pipette methods (Stevens et al., 2011). Analyses at section B were performed on a Malvern Mastersizer S, after the dissolution of carbonates with $10 \% \mathrm{HCl}$, and the addition of Na-pyrophosphate as a dispersant (Zech et al., 2013). These results can be compared, following the relationship of Konert and Vandenberghe (1997).

Detailed malacological results for section A have been published by Sümegi et al. (2016). In their paper, they presented their sampling procedures, as per the determination of mollusk taxa, as well as their ecological interpretation and paleotemperature reconstruction approaches (Molnár and Sümegi, 1990; Sümegi and Krolopp, 2002; Marković et al., 2007; Molnár et al., 2010).

Finally, in order to develop a broad independent chronology for Crvenka, we utilized previously published luminescence and radiocarbon dating results. Twelve samples were taken at section A for optically stimulated luminescence (OSL) and elevated temperature postinfrared stimulated (post-IRSL at $290{ }^{\circ} \mathrm{C}$ ) luminescence dating (Stevens et al., 2011) (Fig. 2). Four selected samples were taken at section B for compound-specific radiocarbon dating on leaf waxes. Analyses were done on the MICADAS (mini carbon dating system) at ETH Zurich (Häggi et al., 2014). Together, these data give Crvenka the most detailed Late Pleistocene independently dated chronology for any site in the southern Carpathian Basin.

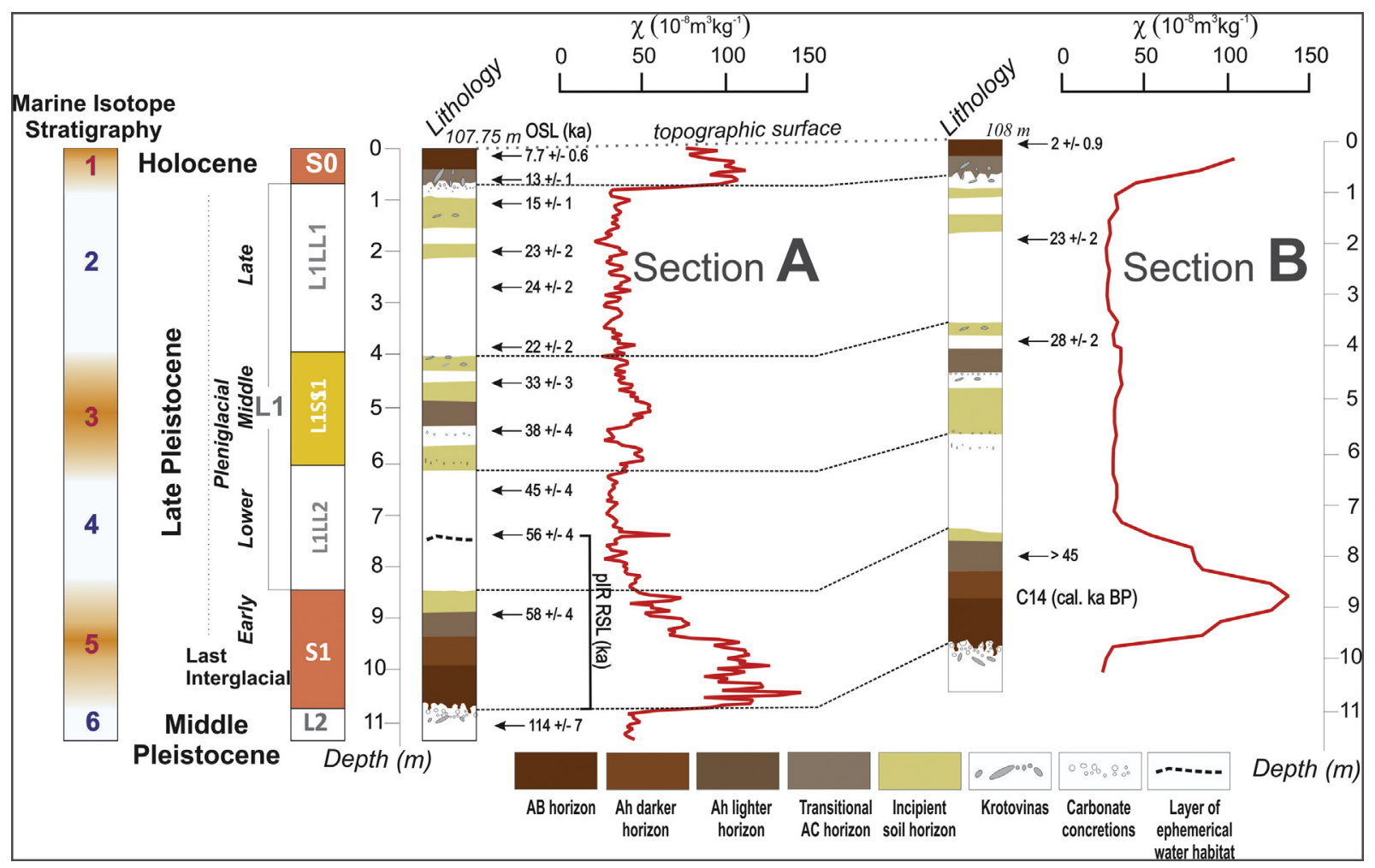

Fig. 2. Lithology of the Crvenka brickyard sections A and B, as related to general stratigraphic interpretations. Sections A and B are located $150 \mathrm{~m}$ apart. Locations of samples recovered for luminescence (Stevens et al., 2011) and radiocarbon dating (Häggi et al., 2014) are indicated by the arrows. Magnetic susceptibility data have been normalized to the maximal value. Interprofile correlations are indicated with dashed lines. The gray line represents the modern soil surface. 


\section{Results}

\subsection{Chronology}

The Crvenka section, with its 12 quartz OSL, seven polymineral post-IR IRSL at $290{ }^{\circ} \mathrm{C}$ (Stevens et al., 2011) and four ${ }^{14} \mathrm{C}$ n-alkane calibrated dates (Häggi et al., 2014), might be the most reliably dated, Late Pleistocene chronology in the Carpathian Basin. These independent radiometric age control approaches are also in good agreement with each other, as well as with their expected geological chronology. Gradual age increases with depth indicate quasi-continuous sedimentation rates, at least on multi-millennial scales. Accumulation rates were highest during the latter part of the last glacial, for the loess sub-unit L1LL1, between $2.0 \mathrm{~m}$ and $4.5 \mathrm{~m}$ depth from the topographic surface. Slightly lower accumulation rates occur in the weakly developed pedocomplex L1SS1 (Stevens et al., 2011).

Variations in loess deposition rates on millennial timescales do not always match shifts in grain-size, suggestive of diverse and complex influences, including changes in the dominant circulation patterns and dynamics of the Danubean hydrological regime, which are at least partially controlled by size and stability of the Alpine ice sheet and vegetation cover. Here we use the recommended combined OSL and PIR IRSL ages, as reported by Stevens et al. (2011), and the AMS ages from Häggi et al. (2014) to constrain the broad chronology of the stratigraphic units preserved in the section.

The luminescence chronology of Crvenka loess-paleosol presented by Stevens et al. (2011) was based both on widely used quartz SAR approaches and on the at that time novel post-IR IRSL technique developed by Thiel et al. (2011). The post-IR IRSL results presented by Stevens et al. (2011) yielded ages that apparently slightly underestimated the proposed stratigraphic age. At publication, the cause of this is unclear, but the match with quartz ages to ca. 60 ka does not necessarily reflect the pIR age accuracy as quartz OSL ages are widely shown to underestimate true ages after ca. $50 \mathrm{ka}$. Thus, although it is possible that the PIR IRSL dates may indicate the soil being early MIS 3 in age, this would result in a chronostratigraphy below this that would be inconsistent with current evidence for cooler, drier glacials and warmer, wetter interglacials/interstadials (as pointed out by the reviewer, it would require thick loess "cold" sediments to be deposited during MIS 5 (after MIS 5e)). We do not completely discard this possibility, but we suggest that it is more likely the pIR ages are underestimating the true depositional age, which is consistent with their match with older quartz ages. We therefore propose that the quartz OSL dating results demonstrate that an accurate independent age model can be applied merely for the last $50 \mathrm{kyr}$ to $60 \mathrm{kyr}$ (Stevens et al., 2011). According to these luminescence chronological interpretations associated with a few additional radiocarbon ages presented by Häggi et al. (2014) it is still not possible to provide an accurate age model for Crvenka loess-paleosol sequence beyond the last ca. $50 \mathrm{kyr}$ with the existing age dataset.

\subsection{Litho- and pedo-stratigraphy}

Most previous stratigraphic studies of loess sections at various exposures in northern Serbian have used lithological, $\chi$ and pedogenic data, along with variations in amino acid racemization geochronology, all combined with luminescence dating, as the primary basis for correlation. The end result has been the establishment of a chronostratigraphy for the various loess-paleosol units in Vojvodinia, a province of Serbia and part of the Carpathian Basin. The nomenclature for this chronostratigraphy follows the Chinese loess stratigraphic system, with one exception - we used the prefix "V-" to refer to the standard Pleistocene loess-paleosol stratigraphy in Vojvodina (Marković et al., 2008). Recently, a Danubian loess stratigraphic model (Marković et al., 2015) has been developed to correlate the loess-paleosol units of the Danube Basin with the Chinese stratotype sections of Louchuan and
Xiefeng. Nonetheless, in our paper the use of the Chinese "L" and "S" labels are applied similarly (e.g. Kukla, 1987; Kukla and An, 1989) without using any regional prefix.

Fig. 2 is a diagram of the LPS, indicating its plateau-like surface, characterized by gentle differences in relative depth and thickness of loess and paleosol units exposed in the A and B profiles. The only stratigraphic discrepancy is the appearance of the layer deposited in a local ephemeral water body in the loess unit L1L2 at profile A. This layer is not visible in profile B.

According to the current chronostratigraphic model for Serbian loess (Marković et al., 2015) and using the high-resolution luminescence dating of the Crvenka profile performed by Stevens et al. (2011). The modern soil (S0) is developed during the Holocene on the top of the composite last glacial loess unit L1, corresponding to marine isotope stage (MIS) 4 through 2. The youngest loess layer (L1LL1) accumulated during the Late Pleniglacial period. The Middle Pleniglacial pedocomplex is represented in the area by a weakly developed soil complex (L1SS1). The lower loess sub-horizon (L1LL2) accumulated above the S1 paleosol. The pedocomplex S1 correlates with MIS 5. Finally, the uppermost part of the penultimate glacial loess (L2) accumulated during the latest part of MIS 6 (Stevens et al., 2011).

The Holocene soil cover on the loess plateau surface, in the area surrounding the Crvenka brickyard, is a typical Chernozem. At the top of the investigated section, the soil profile is $80-\mathrm{cm}$-thick, with a $\mathrm{Ck}$ horizon that contains many $\mathrm{CaCO}_{3}$ nodules $(1-5 \mathrm{~cm}$ in diameter) and numerous krotovinas and root channels filled with humic material. The transitional AC horizon (10YR 5/1-3/3) is 25-cm-thick, porous, and has a silt loam texture and a granular structure. The silt loam Ah horizon (10YR 6/3-4/4) is $40 \mathrm{~cm}$ to $60 \mathrm{~cm}$ thick and has granular structure, along with some carbonate pseudomycelia.

The last glacial loess unit (L1) is 800-675-cm-thick, depending on its location on the paleosurface. The lower loess unit (L1LL2) is a light yellow to gray ( $5 Y$ 7/3 5/3), coarse and porous loess layer; the superimposed weakly developed pedocomplex L1SS1 is intensively bioturbated and contains three weakly developed humic horizons. The uppermost loess layer (L1LL1) is porous and in some parts, heavily bioturbated. In the upper half of this unit, two weak paleosols are developed, each with granular, porous structural aggregates. These initial pedogenetic layers suggest development during more humid environmental conditions. Many spherical, soft, carbonate nodules and humic infiltrations in old root channels are found at the contact with the Holocene soil (S0) above (Stevens et al., 2011).

The reddish-brown pedocomplex (S1), which is 210 to $245-\mathrm{cm}$ thick, is comprised of three pedomembers: a brown horizon (Phaeozem type) at the base, represented by a fossil AB horizon, and two weakly developed fossil A horizons (Chernozem type) that form the middle and upper part of the pedocomplex. The lower, transitional $A B$ horizon (10YR 5/2-3) is darker than the Ah horizon (10YR 6/2-4) above, which contains some preserved carbonate pseudomycelia. The uppermost A horizon is relatively weakly developed and characterized by abundant krotovinas (Stevens et al., 2011).

The basal pale yellow-colored ( $5 Y$ 7/3, 5/4), homogeneous, calcareous loess unit (L2), which is exposed only in the lowest $100 \mathrm{~cm}$ to $130 \mathrm{~cm}$ of the profile, overlies basal stratified gray sands. The contact between the penultimate loess layer (L2) and the S1 paleosol above is characterized by carbonate concretions (1-4 cm dia.) and numerous humic infiltrations associated with root channels (Stevens et al., 2011).

\subsection{Low-field magnetic susceptibility $(\chi)$}

Ever since Heller and Liu (1984) promoted $\chi$ variation as a sensitive paleoclimatic proxy, and one that is easily captured due to the relatively simple measuring procedure (in the field, as well as in laboratory), it has become the most commonly measured loess stratigraphic tool and climate proxy worldwide (e.g. Heller and Evans, 1995). Variations in $\chi$ values in the LPS are generally related to the abundance of 
magnetic minerals, primary magnetite as a rock-forming mineral, and maghemite as a product of pedogenic processes (Singer and Verosub, 2007). In this study, we developed a detailed $\chi$ record measured in the field at every $5 \mathrm{~cm}$ for section A, along with a less detailed (sampling interval $25 \mathrm{~cm}$ ) $\chi$ record from laboratory measurements at section B. The strong accordance of $\chi$ variations with pedostratigraphy suggests that the data represent magnetic enhancement via pedogenesis (e.g. Heller and Liu, 1984; Liu et al., 2013). Despite differences in resolution, $\chi$ variations for profiles A and B show a remarkably similar pattern and are similar to those previously observed in loess-paleosol sequences within the vast semi-arid Eurasian loess belt (e.g. Heller and Evans, 1995; Evans and Heller, 2001; Buggle et al., 2008, 2009; Marković et al., 2014a, 2014b), allowing for stratigraphic correlations across a wide area (Marković et al., 2015).

The two major pedocomplexes, S1 and S0 $\left(>60 \times 10^{-8} \mathrm{~m}^{3} \mathrm{~kg}^{-1}\right)$ have significantly higher $\chi$ values than the loess unit between them (L1) $\left((23-60) \times 10^{-8} \mathrm{~m}^{3} \mathrm{~kg}^{-1}\right)$. The $\chi$ values observed in the penultimate glacial loess (L2) are similar to those in loess unit L1. However, the pedological horizons of the pedocomplex L1SS1 have only slightly higher $\chi$ values than did the loess units L1LL2 and L1LL1.

\subsection{Grain-size distributions}

Variations in grain-size distribution at the Crvenka site correlate well with pedostratigraphy. Generally, pedogenic horizons have a lower proportion of coarse material than do loess layers, not only here but across the main Eurasian loess belt as well (Vandenberghe, 2013; Vandenberghe et al., 2014; Obreht et al., 2016, 2017).

Fig. 3 displays clay contents with depth, for Crvenka sections A and B. As the laser particle analysis method underestimates the clay fraction compared to the pipette analysis (Miller and Schaetzl, 2012), we assumed that the $<6 \mu \mathrm{m}$ fraction, as measured by the laser, is the best correlative to the "pipette clay fraction" as suggested by Konert and Vandenberghe (1997). In spite of the different resolutions and interpretations of the analyses, sections A (Marković et al., 2008; Stevens et al., 2011) and B generally demonstrate similar patterns of particle size distribution. Clay content variations are also similar to the previously presented magnetic susceptibility records, with values as low as $15-21 \%$ in the loess unit L2 and $11-22 \%$ in the loess unit L1, and values

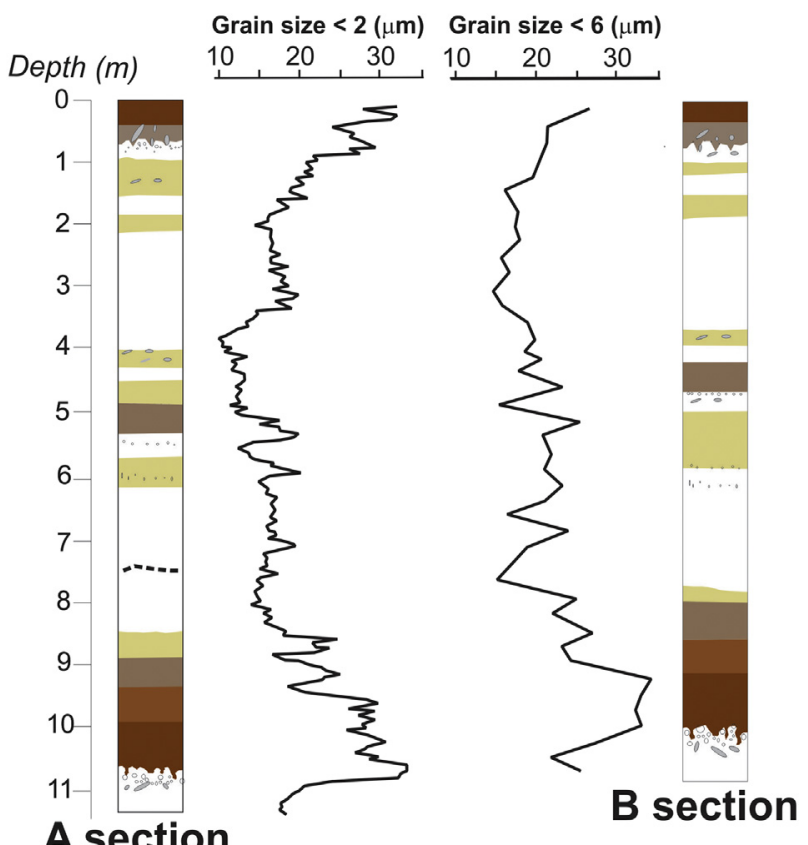

Fig. 3. Comparisons between clay contents at sections $A(<2 \mu \mathrm{m})$ and $B$ $(<6 \mu \mathrm{m})$ (Zech et al., 2013). Lithology and chronology are same as in Fig. 2. as high as $24-35 \%$ in the soils ( $\mathrm{S} 1$ and S0). Clay contents were between $15 \%$ and $25 \%$ in the interstadial pedocomplex L1SS1 (Stevens et al., 2011; Zech et al., 2013) (Fig. 3). Due to mentioned differences in the applied methodological techniques, direct comparison of other grain size fractions at Crvenka A and B sections is problematic. However, observed changes in grain size variations demonstrate the complexity of the climate signal at the study site. Additionally, identified grain size dynamics also indicate multiple influences of complicated and uncertain effect of changes in sediment availability signifying the importance of local vegetation cover conditions and proximity to likely fluvial sources (Stevens et al., 2011).

\subsection{TOC, carbon and nitrogen stable isotope, and n-alkane biomarker characteristics}

Similar to other European loess sequences (Antoine et al., 2001, 2013), variations in TOC values measured at Crvenka B loess section show patterns similar to those presented for $\chi$ and clay data. TOC contents in the Crvenka profile commonly exceed $0.5 \%$, with maximum values $>1 \%$ in the interglacial pedocomplexes (SO and S1), whereas they barely reach $0.3 \%$ in the weakly developed Middle Pleniglacial pedocomplex L1SS1. Loess units contain only $\sim 0.2 \%$ TOC (Fig. 4 ) (Zech et al., 2013).

$\delta^{13} \mathrm{C}$ values of organic matter for the Crvenka LPSs vary between approximately from $-23 \%$ to $-25 \%$, with the more negative values $(-25 \%)$ occurring in the pedocomplex $S 1$ and the less negative values $(\sim-23 \%)$ in the upper part of L1LL1 and the middle part of L1LL2 loess layers. $\delta^{15} \mathrm{~N}$ values of the organic material show an interesting pattern that generally matches the alternations in the LPS stratigraphy, with high values in the interglacial pedocomplex (S1) and in the weakly developed interstadial pedocomplex L1SS1 (Fig. 4). Comparative data are seldom available for LPSs elsewhere, although similar $\delta^{15} \mathrm{~N}$ patterns were described for the Tokaj LPS in northern Hungary (Schatz et al., 2011) and the Belotinac LPS in southern Serbia (Obreht et al., 2014).

The alkane analyses of fossil organic matter in the samples collected during the first field campaign at Crvenka section A revealed the presence of long-chain $n$-alkanes with a pronounced odd-over-even predominance (OEP), suggesting a leafwax origin (Zech et al., 2009). OEP values in the paleosol units are lower than in the loess units, and document-enhanced degradation. This pattern is in agreement with their lower alkane concentrations. Note that normalization of the $n$ alkane concentrations to TOC would further amplify the loess versus paleosol differences. The correlation of the OEP index with the $n$-alkane ratio $\mathrm{C}_{31}$ to $\mathrm{C}_{27}$ indicates that degradation might confound the

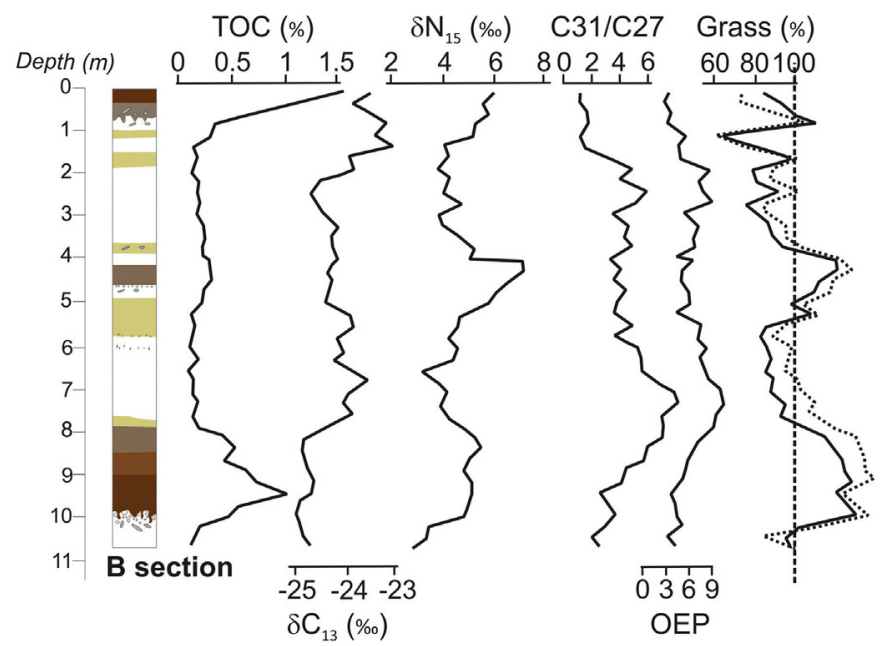

Fig. 4. Comparisons between TOC (\%), $\delta^{13} \mathrm{C}(\%), \delta^{15} \mathrm{~N}(\%)$, and biomarker $n$ alkane records at section B (Zech et al., 2013). Lithology and chronology are the same as at Fig. 2. 
interpretation of alkane ratios in terms of the dominant origin from grasses and herbs $\left(\mathrm{C}_{31}\right.$ and $\left.\mathrm{C}_{33}\right)$ versus trees and shrubs $\left(\mathrm{C}_{27}\right.$ and $\left.\mathrm{C}_{29}\right)$ (Zech et al., 2013). In an attempt to take degradation effects into account, Zech et al. (2009) have suggested corrections using end-member modeling. These 'degradation lines' (in OEP-alkane ratio diagrams) are based on comparison with modern plant samples and soils collected under grass and tree vegetation. Corrected ratios expressed as \% of grass in Fig. 4 for both profiles, consistently show that trees do not contribute significantly to the $n$-alkanes extracted from the MIS 5 and MIS 3 paleosols, whereas during MIS 4, MIS 2, and MIS 1, grasses and herbs were likely not the only, but still clearly dominant sources for the $n$-alkanes. Of course, grass and tree percentages should be regarded as semiquantitative estimates only, and grass percentages $>100 \%$ illustrate the uncertainties and limitations of the end-member modeling approach.

The recent awareness that $n$-alkane concentrations in and under coniferous trees are generally low (Zech et al., 2012) cautions that only estimates of grassland herbs versus deciduous trees and shrubs can be made using this approach. Taking this into account, modified endmember calculations of Zech et al. (2009) are presented here. These modifications result in minor changes in the end-member modeling results, as compared to Zech et al. (2009), but do not affect the general shown in Fig. 4, i.e., trees and shrubs probably contributed somewhat to the preserved $n$-alkanes from MIS 6, MIS 4, MIS 2, and MIS 1, but very likely not during MIS 5 and MIS 3 . In all units, $n$-alkanes of likely grass or herbal origin $\left(\mathrm{C}_{31}, \mathrm{C}_{33}\right)$ clearly dominated.

\subsection{Malacology}

Shells of 9185 land snails (ca. 6500 whole shells and 2700 broken fragments), representing 38 species (four aquatic and 34 terrestrial species), were recovered from 35 samples taken from the Crvenka section (Sümegi et al., 2016). Our malacological data suggest that there are eight mollusk zones in the section (Sümegi et al., 2016). The first and uppermost zone can be placed into the penultimate glacial (L2) loess horizon; it is characterized by the presence of Succinea oblonga, which prefers cold climatic conditions, and the dominance of Pupilla sterri, the eurytopic gastropod Pupilla muscorum, Vallonia costata and Pupilla triplicate, which all favor a mild climate. Based on the calculated dominance values for the individual paleoecological groups, this zone was likely characterized by cold-resistant, mesophilous, Holarctic, Eurosiberian, Central European mountain and xerothermophilous Central and Southeastern European mollusk species (Fig. 5A, B, and C), which reside in relatively cool steppe or forest steppe environments (with mean July temperatures of ca. $15^{\circ} \mathrm{C}$ by the malacothermometer method: Sümegi, 1989, 2005). Thus, our data suggest that July paleotemperatures were $6-7{ }^{\circ} \mathrm{C}$ lower during the latest phase of MIS 6 than are temperatures today (Figs. 5, 6, and 7; Sümegi et al., 2016).

A second malacological zone was identified between 9.0 and $7.7 \mathrm{~m}$ depth (Fig. 5D). It is characterized by the dominance of the warmthloving and mild climate-preferring (xerophilous and mesophilous), and open-vegetation preferring Cochlicopa lubricella, Truncatellina cylindrica, Granaria frumentum, Vertigo pygmaea, Pupilla muscorum, Pupilla triplicata species The forest-steppe environment preferring species Vallonia costata is also significantly abundant here. According to the malacothermometer, the July paleotemperature at this time was between $18^{\circ} \mathrm{C}$ and $20^{\circ} \mathrm{C}$, which compares to modern July temperatures of approximately $21^{\circ} \mathrm{C}$ (Hrnjak et al., 2014). Decreases in cold-resistant species also occur in this zone, accompanied by an increase in mild and xerophilous steppe and forest steppe forms. Shade-loving and hygrophilous species are absent from the malacofauna of this second zone (Sümegi et al., 2016).

The third malacological zone is developed between 7.7 and $7.2 \mathrm{~m}$ depth (Fig. 5D). It represents a considerable change, when compared to the earlier zones. This zone is characterized by the disappearance of Truncatellina cylindrica and Vertigo pygmaea, and the decreasing

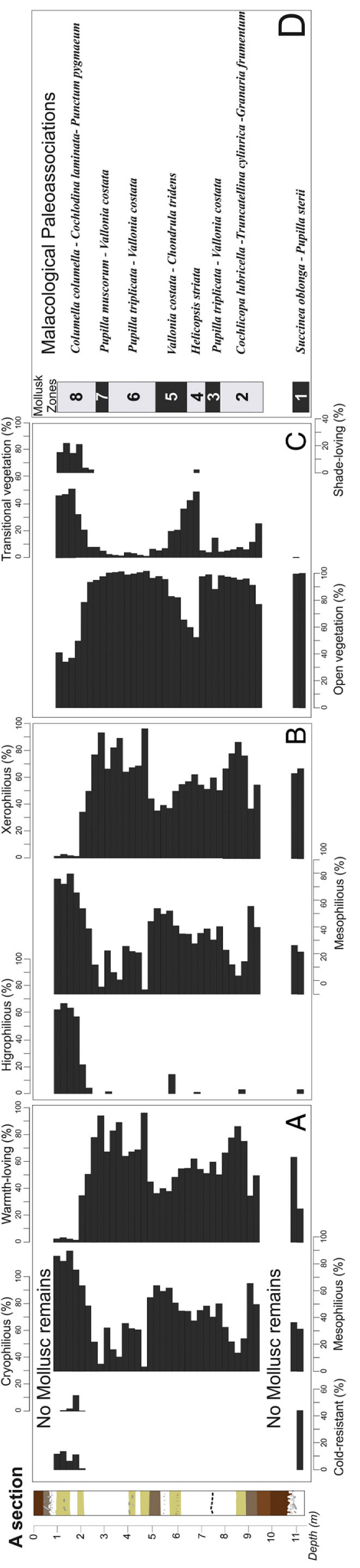

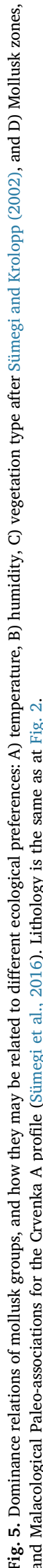


abundances of Granaria frumentum and Chondrula tridens. Vallonia costata (Holarctic spreading, forest steppe preferring) and Pupilla triplicata (preferring steppic environment) dominate in this zone (Sümegi et al., 2016).

The fourth malacological zone is found between 7.2 and $6.2 \mathrm{~m}$ depth (Fig. 5D). As compared to the third malacological zone, no changes in the qualitative composition of the malacofauna occur in this zone. Nonetheless, the species dominance changes dynamically. Especially notable is the dominance of the warm-loving, xerophilous and open habitat preferring Helicopsis striata (20-46\%). The species Vallonia costata and Chondrula tridens also gain greater importance, whereas there is a drop in the dominance of Pupilla triplicate species. Based on the calculated dominance values of the individual paleoecological groups, this zone was characterized by mesophilous, xerophilous, mild climate preferring Holarctic, Central and Southeastern European mollusk species that reside in mild steppe or forest steppe environments. These suggest that July paleotemperatures were between $17^{\circ} \mathrm{C}$ and $18{ }^{\circ} \mathrm{C}$, i.e., only $3-5{ }^{\circ} \mathrm{C}$ lower than today (Sümegi et al., 2016).

The next lower (fifth) malacological zone is located between 6.0 and $5.0 \mathrm{~m}$ (Fig. 5D), where the peak of Holarctic mesophilous forest steppe preferring Vallonia costata (47-64\%) and warmth-loving, xerophilous and open habitat preferring Chondrula tridens (5-6\%). July paleotemperatures for this period were about $18^{\circ} \mathrm{C}$, based on the malacothermometer method (Sümegi et al., 2016).

The sixth malacological zone is located between $5.0 \mathrm{~m}$ and $3.0 \mathrm{~m}$ depth. The distinguishing feature of this horizon is a drastic decrease in the number of Vallonia costata, accompanied by a considerable increase in the dry, open vegetation habitat preferring Pupilla triplicate (58-93\%) fauna. The latter tend to populate carbonate-rich, open vegetation on the mountain and hilly regions in Central Europe. The general composition of the fauna and the presence of such species as Granaria frumentum, Vertigo pygmaea, Helicopsis striata in this zone suggest less grass cover at this time (Fig. 5D), for large parts of the surface, as compared to the previous zone below (Sümegi et al., 2016).

The fauna changed significantly between $3.0 \mathrm{~m}$ and $2.5 \mathrm{~m}$, in the seventh malacozone (Fig. 5D). The ratio of thermophilous species decreased significantly. However, a few specimens of Cochlicopa lubricella, Granaria frumentum, Pupilla triplicata, Chondrula tridens and Helicopsis striata remain present in this zone. This faunal change indicates a transition from a mild-dry to a cold-wet environment (Sümegi et al., 2016).

Rather important changes are also observed in the sixth zone (2.50-0.85 m) (Fig. 5D). Cold-loving and cold-resistant forms (Columella columella, Columella edentula) are dominant here. Despite the significant increase of species requiring greater vegetation cover, the most important paleoenvironmental indicator species of this group (e.g. Clausilia pumila, Clausilia dubia, Cochlodina laminata, Vitrea crystallina, Aegopinella ressmanni, Arianta arbustorum, Orcula dolium, Bradybaena fruticum, Discus ruderatus, Semilimax semilimax, Punctum pygmaeum) occurred in this zone. Shade-loving and intense vegetation cover-preferring mollusks comprised of $50-70 \%$ of the total molluskan assemblage of this zone. The most important change in this horizon is the decrease in the proportion of warmth-loving steppe environment preferring species such as Granaria frumentum, Pupilla triplicate, Chondrula tridens, Helicopsis striata and mesophilous Vallonia costata, accompanied by a considerable increase in the number of hygrophilous, cold-resistant, open vegetation habitat preferring European fauna, such as Trichia hispida and Trichia striolata. These data suggest that July paleotemperatures were between 13 and $14{ }^{\circ} \mathrm{C}$ during this phase, which is $7-9{ }^{\circ} \mathrm{C}$ lower than today (Fig. 5). The highest diversity of the mollusk fauna is also found in this horizon (Sümegi et al., 2016). Additionally, this malacozone is associated with the highest number of mollusk shells per unit volume of sample, indicating a denser vegetation cover. This fact coincides with surprisingly fine grain size composition, recorded in the uppermost part of L1LL1 loess sub-unit (Marković et al., 2008).

\section{Discussion}

Extant knowledge of paleovegetation dynamics during the Late Pleistocene on loess plateaus in the Carpathian Basin is still scarce. Our knowledge is mostly based on mollusk shells and plant macrofossils in loess deposits (Rudner and Sümegi, 2001; Sümegi and Krolopp, 1995, 2002; Feurdean et al., 2014). To fill this data gap, we have combined results from traditional malacological studies with novel $n$-alkanes biomarker analysis to establish a more accurate paleovegetation reconstruction for the region.

This study has made the Crvenka section the most intensively investigated Late Pleistocene loess site in the southeastern Carpathian Basin. Classic paleoclimatic and environmental proxies at Crvenka, such as $\chi$, grain size, and geochemical indices, show similar patterns to other investigated loess sites in the Vojvodina region (Marković et al., 2005, 2008, 2014a, 2014b; Bokhorst et al., 2009; Buggle et al., 2011, 2013; Antoine et al., 2013; Hatté et al., 2013; Gavrilov et al., in press). This correlation indicates that the Crvenka site can be regarded typical for the region, and thus, the new paleoenvironmental proxies we present may be considered as representative for the entire southern Carpathian basin, for which knowledge of paleovegetation is still poor.

\subsection{Evaluation of existing Crvenka loess-paleosol sequence chronology}

Age control is central to the interpretation of loess climate proxies. The choice of method for age-dating is critical as on sub-orbital timescales non-independent/non-radiometric dating methods such as orbital tuning can be inaccurate and fail to capture the extent of variations in loess accumulation (Stevens et al., 2007). Luminescence dating methods have been of critical importance in the development of loess chronologies and, in turn, the development and testing of luminescence dating protocols themselves (Roberts, 2008). The key advantages of luminescence over other methods are that the technique directly dates deposition, utilises abundant clastic material such as quartz, and potentially can be used to date back over into the middle Pleistocene (Roberts, 2008; Buylaert et al., 2012; Murray et al., 2014; Marković et al., 2015).

In spite of the evidence that the luminescence ages for the loess subunit L1LL2 at Crvenka A section (Stevens et al., 2011) correspond more with late MIS 3 than with the expected geological age related to MIS 4 (e.g. Marković et al., 2008, 2015) we would still argue that the L1LL2 loess horizon is most likely formed during the MIS 4. Fuchs et al., (2008) dated the same stratigraphic subunit L1LL2 at Surduk section with ages ranging from approximately $52.4 \pm 6$ ka to $82.6 \pm 9.6 \mathrm{ka}$ indicating that the loess formation continued even to MIS 5a. Detailed correlation between stratigraphies of Surduk and Crvenka sections indicated a high level of similarities. These chronological interpretations were recently confirmed by high-resolution OSL dating of the Veliki Surduk core at Titel loess plateau by Perić et al. (in press). Bokhorst et al. (2009) also provided OSL ages older than $60 \mathrm{ka}$ for the loess subunit L1LL2 at Titel old brickyard section. Independent evidence of malacological assemblages observed in L1LL2 subunit that were analyzed on all sites in Northern Serbia always indicated significantly drier environmental conditions than in L1LL1 and L1SS1 subunits (e.g. Marković et al., 2008). After a careful cleaning of exposures and during detailed profiles description as well as during correlation of loess stratigraphy at the long loess exposures in Crvenka brickyard we did not observe any erosion features. Discreet feature indicated by 8 in Legend of Fig. 2 is just an indication of a small temporal water body characterized by limited volume. Thus, the presence of a significant erosional hiatus at least on a multi-millennial level is hardly possible at the investigated section. Additionally, previous results of AAR relative geochronology provides independent support to the statement that the last glacial loess unit L1Ll2 is mostly chronological equivalent to MIS 4 (Marković et al., 2004, 2005, 2006, 2007, 2008, 2015). Same studies about AAR relative geochronology also support the statement that the 
pedocomplex S1 was developed during the MIS 5. Younger than expected ages for the upper part of loess unit L2 presented by Stevens et al. (2011) at Crvenka A section as well as Fuchs et al. (2008) at Surduk might also be the result of significant bioturbation features (root channels, krotovinas and secondary carbonates) below the overlying pedocomplex S1 and partly by the possible limitations of the dating technique (e.g. Murray et al., 2014). For the establishment of a valid loess chronology of Crvenka loess-paleosol sequence we need a high resolution dating of this section using different protocols and luminescence dating techniques. Until then, we will use this generalized chronostratigraphy for the Crvenka loess-paleosol sequence valid for broad correlations with equivalent European loess records.

\subsection{Paleovegetation reconstruction based on the mollusk fauna}

Only two relatively cold climatic phases can be observed from the Crvenka mollusk fauna data, over the last ca. $150 \mathrm{kyr}$. Both of these cold periods appeared in the latest phases of the formation of the penultimate glacial and the last glacial loess units, L2 and L1 respectively. These units were deposited just before the development of the last interglacial and modern soils, S1 and S0. The older of these stadial phases, L2 (Stevens et al., 2011), is characterized by the appearance of Succinea oblonga and domination of Pupilla sterri steppe elements (Sümegi et al., 2016). On top of this loess layer lies the youngest Middle Pleistocene loess layer, within which is developed a strong pedocomplex (S1) formed during the last interglacial and Early Pleniglacial phases. No land-snail shells were found in the lower and middle parts of paleosol S1, likely due to poor preservation and leaching of primary carbonates in the soil.

Environmental reconstruction of the third malacological zone suggests that the loess here was deposited under relatively similar conditions to the Holocene. Faunal composition in this zone is similar to recent loess and sand steppe malacofauna in the southern and southeastern part of the Great Hungarian Plain, where only Pupilla triplicate species are missing in the current faunal suite (Sümegi, 2005). Among these, the xeromesophilous, carbonate preferring $\mathrm{Pu}$ pilla triplicata species were present at several locations on the Hungarian Great Plain at the beginning of the Holocene (Sümegi, 1989, 2005), but shortly thereafter, its range was reduced to carbonate-rich, open vegetation habitats at higher altitudes. These data suggest that Pupilla triplicate lived in the Crvenka region until the 3rd millennium B.C. (Sümegi and Szilágyi, 2010, 2011). Therefore the malacofauna from the S1 interglacial soil and early L1 loess layers are similar to the Early Holocene mild temperate steppe-forest steppe malacofauna on the Great Hungarian Plain.

The next loess layer, L1LL2 (7.0-5.5 m depth), was deposited on a typically dry and mild loess steppe-forest steppe environment where short grassland covered about $50 \%$ of the surface. The malacofauna composition of this layer suggests that the lower summer temperatures were accompanied by higher humidities and vegetation densities. In the upper part of L1LL2, environmental conditions then noticeably changed. This Vallonia costata - Chodrula tridens zone developed in a typical mild forest steppe environment throughout the region, as humidity and vegetation cover increased. This change may reflect reforestation, associated with higher atmospheric moisture conditions. This loess layer formed on a typically mild, loess forest steppe environment, where short grassland covered $<40 \%$ of the surface (Fig. 5). The L1SS1 interstadial paleosol and the lower part of the L1LL1 soil both formed in a typically dry and warm steppe environment where short grassland covered $>60 \%$ of the surface (Sümegi et al., 2016).

Although the dominance of molluskan species changed after the terminal phase of the last interglacial cycle, the composition of malacofauna did not change in the early phase of this glacial cycle. In the Crvenka region, a temperate steppe to forest-steppe environment survived during the Early and Middle Pleniglacial, under a mild and dry climate phase. Notably, there was no imprint of permafrost at this time, based on stratigraphic evidence and the composition of the mollusk fauna during Early and Middle Pleniglacial phases in the region (Sümegi et al., 2016).

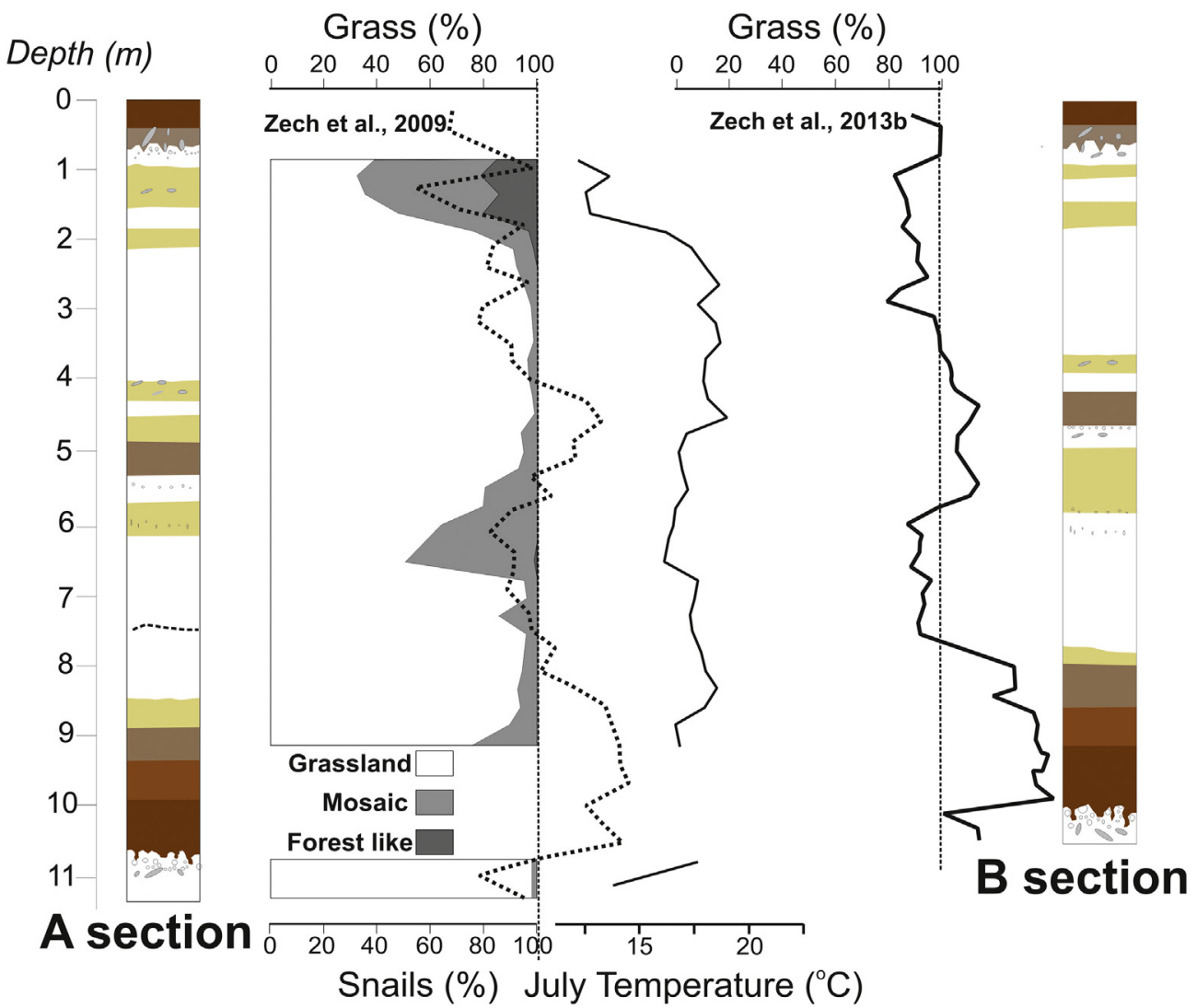

Fig. 6. Comparison between mollusk assemblages related to the grassland, mosaic forest, and forest-like vegetation types, using $n$-alkane biomarker data (Zech et al., 2009) and July paleotemperatures obtained at section $\mathrm{A}$, as well as the $n$-alkane biomarker record at section $\mathrm{B}$ (Zech et al., 2013). Lithology and chronology are same as at Fig. 2. 
During the Late Pleniglacial phase, the composition of malacofauna changed dramatically; cold-resistant, cryophilous and shade-loving species became abundant in the Crvenka profile. All these changes seem to point to the emergence of a colder climatic period, which is likely coeval with the dominance peak of the Boreo-Alpine Columella columella observed during Late Pleniglacial phase in the southern part of the Great Hungarian Plain (Sümegi and Krolopp, 2002; Sümegi, 2005; Hapuczi and Sümegi, 2010). As the July paleotemperature at this time was reconstructed to be $7-9{ }^{\circ} \mathrm{C}$ lower than today, the dominant peak of the shade-loving mollusk suggests that the lower summer temperatures also coincided with higher humidities and vegetation densities (Figs. 6 and 7).

The composition of the mollusk fauna indicates that a mosaic-like environment developed during the Late Pleniglacial dust accumulation phase. This environment was characterized by tundra-like conditions, with the Boreo-Alpine and mesophilous steppe-forest steppe environment preferring Holarctic taxa, and shade-loving Central European, European, and Alpine mountain elements coexisting. This mosaic-like vegetation cover must have been favorable for the expansion of both woodland and open vegetation habitat-preferring elements of mollusks as well. The composition of the fauna refers to mosaic-like foreststeppe-open grassland vegetation within tundra-like openings, and a cool but humid climate prevailing during this dust accumulation period. High humidities during this cool phase were favorable for many types of mollusk fauna, leading to high mollusk densities.

4.3. Comparison between environmental reconstructions based on classic malacological analyses and novel n-alkanes biomarkers

In this study, mollusk-based paleoenvironmental reconstructions provide the first direct and independent evidence to support the previously presented findings from $n$-alkane biomarkers. Thus, by extension, these reconstructions confirm the validity of $n$-alkane based vegetation reconstruction from loess sites.

The total concentration of long-chain $n$-alkanes ( $\mu \mathrm{g} / \mathrm{g}$ dry weight) in the sediments at Crvenka generally correlate with an abundance of warm loving snails and warmer climatic conditions, as indicated by the mean July malacothermometer temperature (Fig. 7). The high concentrations could either reflect higher $n$-alkane input from vegetation or better $n$-alkane preservation in the soil/sediment. However, as OEP variations are only slight, pronounced preservation-degradation effects can likely be excluded (Fig. 4). Peaks of $n$-alkane concentrations also coincide with total molluskan abundance, indicating potentially higher ecosystem productivity during these intervals.

The $n$-alkane biomarker records from Crvenka (Fig. 7) had previously been discussed regarding their implications for paleovegetation by Zech et al. (2009, 2013). Zech et al. (2009) challenged the standard paradigm of a treeless glacial environment in the southeastern Carpathian Basin at this time. So far, this finding has only been supported by wood charcoal data from the Hungarian part of the Carpathian Basin (Willis et al., 2000). To date, no charcoal data have been reported for the Vojvodina region. Based on the $n$-alkane patterns $\left(\mathrm{C}_{31}\right.$ dominance), Zech et al. (2013) postulated the continuous predominance of grassland ecosystems at Crvenka during the Late Pleistocene, for loess layers L1LL2 (MIS 4) and L1LL1 (MIS 2). However, based on $n$-alkane data that indicated an increase in arboreal abundance in the paleoflora in L1LL2 (MIS 4) and L1LL1 (MIS 2).

With regard to these biomarker findings, Zech et al. (2013) questioned whether periods of loess formation periods might have been more humid than periods of soil (paleosols) formation. Although commonly used proxies, such as $\chi$, grain size and TOC, illustrate pedogenesis intensity and are therefore directly influenced by dust

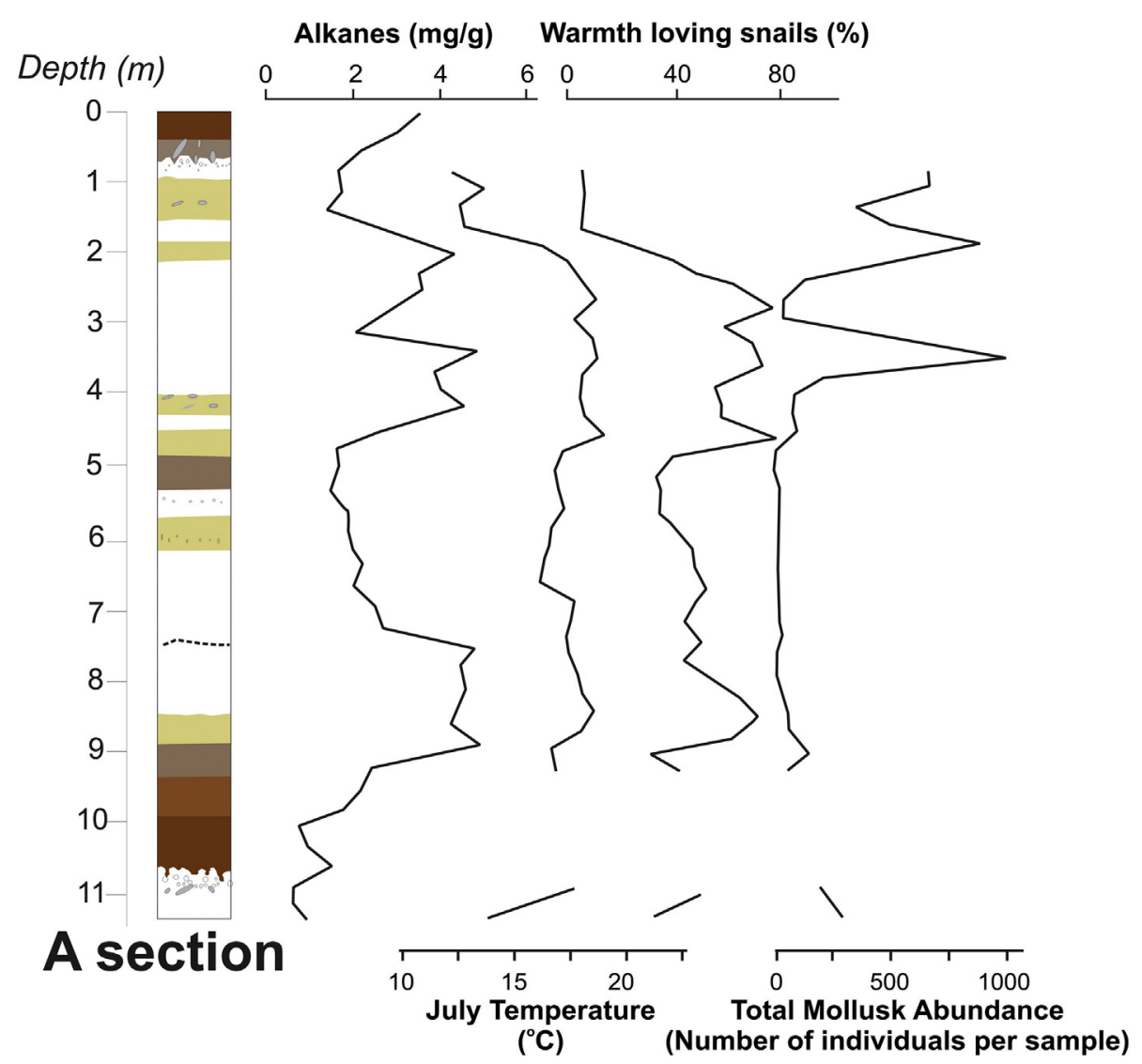

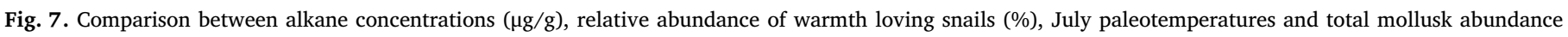
(number of individuals) at section A. Lithology and chronology are same as at Fig. 2. 
accumulation rates, $n$-alkane biomarker composition is not directly influenced by loess deposition intensity. As the plant biomarkers reflect the relative composition of the paleovegetation, they provide an indirect proxy for climatic parameters of more ecological relevance, i.e. they record climatic changes as experienced by the vegetation. Accordingly, the suggested increased abundance of trees in the southeastern Carpathian Basin during glacial periods may not indicate increased precipitation, as hypothesized by Zech et al. (2013). Rather, it may reflect reduced moisture stress as a result of higher edaphic humidity due to reduced evapotranspiration under cooler climatic conditions. This conclusion is in agreement with the notion that parts of southeastern Europe served as refugia for deciduous trees during glacial periods (e.g. Tzedakis et al., 2006). Paleovegetation-based proxies such as $n$-alkane biomarkers therefore, provide a different perspective on paleoenvironmental reconstruction.

Nonetheless, certain issues demand caution when interpreting $n$ alkane biomarker records. Because $n$-alkane biomarker research in loess is still in the developmental stages, uncertainties still remain regarding the $n$-alkane signature biomarker patterns of many plant species, and the chemotaxonomic value of $n$-alkanes. In some regions, exceptions from the classical $n$-alkane distribution of $n$ - $\mathrm{C}_{27}$ and $n$ - $\mathrm{C}_{29}$ homologues being typical for trees and shrubs and $\mathrm{C}_{31}$ and $\mathrm{C}_{33}$ for grasses and herbs have been reported (Maffei et al., 2004; Diefendorf et al., 2011; Bush and McInerney, 2013; Tarasov et al., 2013). In addition, for some species, a climatic control on $n$-alkane pattern has been observed, indicating possible shifts toward higher chain length with increasing aridity and/or temperature (Dodd and Afzal-Rafii, 2000). Deficits also exist in the understanding of the evolution and modification of the $n$ alkane signatures from plants to soil and sediments. Specifically, although many individual plant species have been subject to $n$-alkane analyses, there remains an insufficient amount of knowledge about $n$ alkane fingerprints for ecosystems in soils or sediment. Nevertheless, a recent European transect study on modern soils corroborates the general validity of the $n$-alkane biomarker approach for distinguishing between trees and shrubs versus grasses and herbs (Schäfer et al., 2016).

Because plant derived organic matter in soils and sediments represents a mixture of materials from various plant sources with a different $n$-alkane concentration in the tissues and different incorporation rates of leaf waxes into the soil (e.g. Zech et al., 2012), the interpretation of $n$-alkane records is complicated. In addition, $n$-alkane records might be biased by post-sedimentary overprint of the leaf-wax derived alkanes by alkanes of different sources, e.g., $n$-alkanes derived from microorganisms (see Buggle et al., 2010 and references therein; Zech et al., 2013), yet recent studies applying radiocarbon dating on alkanes from LPS show that these effects are negligible (Häggi et al., 2014).

Nonetheless, the malacological results at the Crvenka section are generally in agreement with the $n$-alkane biomarker records from the site, as reported by Zech et al. $(2009,2013)$. These data suggest that the potential biases mentioned above are of minor significance in this instance. Fig. 7 shows the $n$-alkane modeling results for sections A and B, as well as the distribution of forest like, mosaic and grassland snail assemblages over section A, associated with July paleotemperatures and plotted by depth. The continuous predominance of grassland ecosystems during the Late Pleistocene, as shown in Fig. 7, is also independently confirmed by mollusk data. The presence of a forestgrassland mosaic landscape in MIS 4 and MIS 2 is also supported by mollusk data, thereby validating the biomarker approach.

Despite indicated general agreement between these two independent biological proxies, some limitations related to accurate interpretations of these proxy records still exist. For example, periods with domination of snail assemblages related to dry and open habitats can be associated with relative low grassland dominance (around $80 \%$ of grassland dominance, L1LL1 from $2.8 \mathrm{~m}$ to $3.5 \mathrm{~m}$ depth) as well as with complete domination of grass environments ( $>100 \%$ of grassland dominance, L1SS1 around $4.75 \mathrm{~m}$ depth). Hence, classic malacological investigations still provide more detailed and valuable information for environmental reconstruction than interpretations based on $n$-alkanes. Thus, a common application of the novel $n$-alkanes approach to paleovegetation reconstruction associated with different traditional bioindices such as: land snail and pollen assemblages, plant macro fossils, phytoliths or rhizoliths is more than welcome.

Additionally, $n$-alkanes may provide the key to paleovegetation reconstruction from the interglacial paleosols S0 and S1, where mollusks are either rare or absent due to pedogenic acidification and hence, carbonate leaching. Unlike mollusk shells, $n$-alkane biomarkers are preserved in leached horizons like decalcified paleosols, and thus, they may provide the best proxy for paleoflora. As shown by the data from the Crvenka site, a direct comparison of $n$-alkane based reconstruction of local paleovegetation and mollusk records for local habitat conditions provides a promising method for insight into paleoecological conditions.

In sum, although the long-chain, plant-derived $n$-alkanes at the Crvenka LPS suggest a minor, but the non-negligible contribution of deciduous trees and shrubs $\left(\mathrm{C}_{27}\right.$ and $\left.\mathrm{C}_{29}\right)$ during MIS 1, MIS 2, MIS 4, and MIS 6, they provide no evidence for widespread forest cover during MIS 3 and MIS 5. Hence, from the biomarker and plant ecological perspective, soil conditions on the Carpathian loess plateaus seem to have been more arid (higher dry stress for plants) during MIS 3 and MIS 5 than during MIS 2, MIS 4, and MIS 6.

\subsection{Stable isotope composition of organic matter in the light of the malacological inventory}

$\delta^{13} \mathrm{C}$ values for the Crvenka LPS vary from $-23 \%$ to $-25 \%$, which is within the range for almost pure C3 vegetation (Hatté et al., 2013), but represents a slightly more positive value than would be expected for typical C3 vegetation $(-25 \%$ to $-27 \%$ ). Such carbon isotope enrichment by few \%o could result from organic matter degradation (e.g. Zech et al., 2013). However, at Crvenka those units with less negative carbon isotope signature (base of L1LL2, top of L1LL1) do not correspond with minima in the OEP, serving as an alkane-degradation proxy. In general, we assume that degradation of organic matter is less pronounced in the loess units due to high sedimentation rates and thus, more rapid burial of organic matter. Accordingly, OEP values (3-6) recorded in the $\mathrm{S} 1$ paleosol are lower than those observed in loess. The carbon isotope signature of the S1 loess $(-25 \%)$, however, is more negative than for the loess. Hence, a significant contribution of degradation-related carbon isotope fractionation in the loess-paleosol strata of Crvenka appears unlikely.

Slight carbon isotope enrichment in the L1LL2 and L1LL1 soils could also have resulted from C3 vegetation under moisture stress, although this hypothesis is not supported by the relative abundance of xerophilous and hygrophilous snails. Alternatively, small contributions by C4 plants could explain a carbon enrichment of $\sim-1.5 \%$ to $-2 \%$ o between the last interglacial paleosol and the local maxima in last glacial loess. Assuming an average $\delta^{13} \mathrm{C}$ signature of $-27 \%$ and $-12 \%$ for C3 and C4 plant-derived material respectively an estimation of the contribution of $\mathrm{C} 4$ plants can be obtained using an isotope mass balance calculation. Accordingly, the ${ }^{13} \mathrm{C}$ enriched strata of the L1LL1 and L1LL2 loess units would have had a contribution of $\sim 27 \%$ of C4derived carbon, which is about twice as high as calculated for the last interglacial pedocomplex (S1) at Crvenka. Generally, the combination of higher atmospheric $\mathrm{CO}_{2}$ levels, lower temperatures, and higher precipitation totals favor $\mathrm{C} 3$ plants over $\mathrm{C} 4$ plants. The contemporary crossover temperature to a dominance of $\mathrm{C} 4$ species is related to atmospheric $\mathrm{CO}_{2}$ contents, and is today at about $22^{\circ} \mathrm{C}$ for the mean temperature of the growing season. In the BLP, the main growing season under modern climate conditions is between May and June, which is coeval with the primary period of precipitation. For these months, the mean temperatures are below the crossover temperature. 

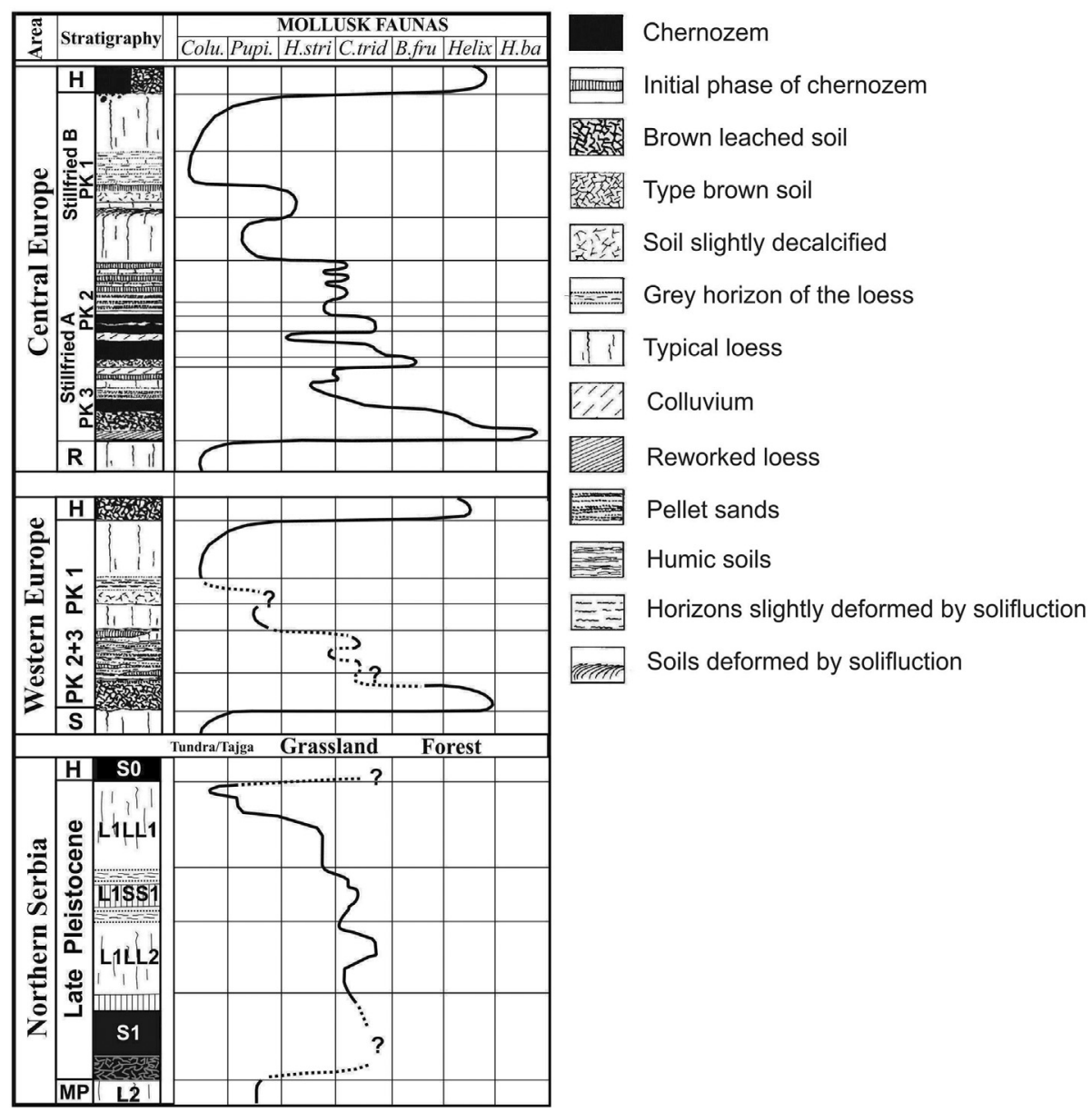

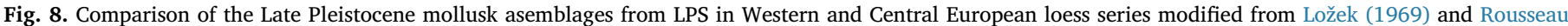

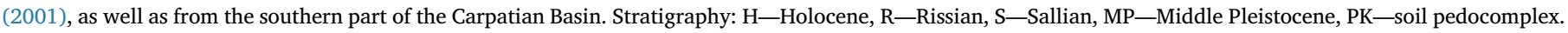

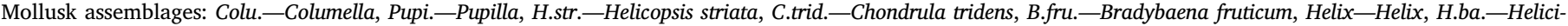
gona banatica. Interst.-Interstadial, Intergla.-Interglacial.

Collins and Jones (1985) reported a C4 contribution of $<2 \%$ for the modern flora of this region. During the Last Glacial Maximum (LGM), the atmospheric $\mathrm{CO}_{2}$ level was ca. $180 \mathrm{ppm}$ or between $220 \mathrm{ppm}$ and $240 \mathrm{ppm}$ during interstadials of the last $40 \mathrm{kyr}$ (Jouzel et al., 1993). In these cases, the crossover temperatures would have been much lower, about $10^{\circ} \mathrm{C}$ and $12-13{ }^{\circ} \mathrm{C}$, respectively.

The mollusk shell data consistently point to July paleotemperatures higher than $13{ }^{\circ} \mathrm{C}$, even for the LGM. However, the $\delta^{13} \mathrm{C}$ values at Crvenka do not indicate a dominance of $\mathrm{C} 4$ vegetation during this period. Most likely, the elevated carbon isotope signatures in the glacial units reflect a slight spreading of C4 vegetation onto the BLP. In the glacial units of the section, alkane patterns and snail assemblages also indicate a spread of tree vegetation and grass-tree mosaic vegetation, contemporary with carbon isotope enrichment. Following Obreht et al. (2014), this suggests that the increased contribution of C4 grasses is counterbalanced by a decrease of grassland-derived (C3 and C4 vegetation) organic matter vs. tree-derived organic matter (C3 vegetation). Such a change might explain the absence of a pronounced C4 dominance even though the crossover temperature had been surpassed. Similar observations have been reported from other late Pleistocene loess sites in the Carpathian Basin (Schatz et al., 2011; Hatté et al., 2013), which show only a slight, or even no, isotopic evidence for C4 plant expansion. In contrast to carbon, the nitrogen data show ${ }^{15} \mathrm{~N}$ isotopic enrichment in the interglacial and interstadial paleosols. This enrichment has also been reported from other loess sites in the Hungarian part of the Carpathian Basin, as well as from Southern Serbia (Schatz et al., 2011; Obreht et al., 2014). Following Schatz et al. (2011) and Zech et al. (2013), the isotopic enrichment of nitrogen in fossil soils can be regarded as an indicator of open $\mathrm{N}$-cycles due to higher biomass production during the interglacials and especially interstadials, rather than due to intensive biomass decomposition.

\subsection{Comparison with the Late Pleistocene records preserved in other European loess provinces}

Fig. 8 compares generalized mollusk successions preserved in the LPSs of Central and Western Europe (Ložek, 1964; Rousseau, 2001) with data from the Vojvodina region. The Late Pleistocene environments in Central and Western Europe range from glacial tundra like (represented by Columella columella fauna), to different types of grasslands (represented by Pupilla species, Helicopsis striata and Chondrula tridents) and transitional environments (Bradybena fruticum), to interglacial humid deciduous forest habitats (represented by Helicigona banatica fauna types). Simultaneously, the continuous predominance of grassland habitats has been observed in the Vojvodina region (Fig. 8). The main reason for these environmental differences is the increase in continental climatic influences, corresponding to increasing distance from the Atlantic Ocean. In addition, current as well as Late Pleistocene summer temperatures in the Middle and Lower Danube region appear to be significantly higher than in other European loess provinces. The similarity between the present and Pleistocene temperature gradients over the European loess belt has previously been pointed out by Sümegi (2005), Krolopp and Sümegi (1995), Sümegi and Krolopp (2002), and Marković et al. (2006). Based on these paleoclimate reconstructions, 
other European loess provinces are best classified as 'cold humid' in Western Europe and 'cold temperate humid' in Central and Eastern Europe. These loess provinces are characterized by significantly different paleoenvironmental conditions than the 'temperate dry' loess province in the southeastern Europe (Smalley et al., 2011). This "temperate dry" generally warmer semi-arid, southeastern European loess province is the westernmost part of a transcontinental loess belt the most westerly extension of the Central Asian (e.g. Dodonov and Baiguzina, 1995; Bronger et al., 1995; Machalett et al., 2008) and Chinese loess provinces (e.g. Kukla, 1987; Kukla and An, 1989; Porter, 2001).

The loess mollusk fauna of Crvenka and other sites in the Carpathian Basin are characterized by a small number of cold-resistant species, suggesting a stable, dry, and relatively warmer glacial climate, as compared with other European loess localities. Furthermore, the data presented here suggest that the loess plateaus in the Vojvodina region were a type of refugium in Europe for steppic, warm-loving and xerophilus mollusk taxa during the otherwise unfavorable glacial climates of the Late Pleistocene. Recently, Sümegi et al. (2016) described the Vojvodina region as being more like transitional biogeographical zone, rather than a refugium per se.

Finally, snails as well as alkane biomarker data indicate the presence of tree-grassland mosaic vegetation during the last glacial period (MIS 2). Although Western and Central European vegetation records generally indicate a decline of tree vegetation during glacial periods, suggesting a treeless glacial paleoenvironment, the findings at Crvenka indicate a small but gradual increase in trees during the glacial periods for the BLP. Under modern and interglacial conditions, edaphic dryness represents the major factor limiting tree expansion in the central Carpathian Basin, whereas cooler glacial conditions provide less moisture stress and higher edaphic humidities, explaining the expansion of trees during the loess depositional periods for layers L1LL1 and L1LL2. In addition, although western and central Europe forest vegetation apparently was limited by low summer temperatures, glacial summer temperatures in Carpathian Basin were actually higher during the Late Pleistocene (Schreuder et al., 2016). In regions where there is no permafrost providing an additional source of humidity, precipitation during the LGM might have been too low to support trees. These findings help explain why the Balkan Peninsula is one of the most important European biodiversity hotspots and a potential forest refugium during glacial periods.

\section{Conclusions}

Over the last several years, investigations of the Crvenka LPS have established the importance of this site as a valuable record of Late Pleistocene paleoclimate and paleoenvironment in northern Serbia in particular, and for the southeastern Carpathian Basin in general. As the most extensively investigated Serbian exposure, this site enables the possibility of reconstructing local and regional environmental processes and conditions during the last approximately $150 \mathrm{kyr}$.

Unlike data from other parts of Late Pleistocene Europe, our results provide unique proxy data for the environmental evolution in the Carpathian Basin. We present two independent lines of environmental evidence from this loess-paleosol section: novel $n$-alkane biomarkers and traditional land snail assemblages. These data are augmented by grain size, magnetic susceptibility and stable isotopic data. With these data, not only can the validity of the biomarker approach be assessed, but also, both types of records independently confirm a relative stable paleoenvironment during the entire Late Pleistocene, characterized by the continuous dominance of grassland vegetation. Although interglacial conditions were generally characterized by dry steppic environments, grassland-tree mosaic vegetation did develop during the glacial periods at Crvenka. These findings highlight the Carpathian Basin, specifically its southeastern part, as an important area for the preservation of biodiversity during the past $150 \mathrm{kyr}$.

\section{Acknowledgments}

This research was financially supported by Project 176020 of the Serbian Ministry of Education and Science and grant F-178 of Serbian Academy of Sciences and Arts. F.L., C.Z., W.C., and I.O. acknowledge the financial support from a grant the Collaborative Research Center (CRC) 806 grant of the German Research Foundation (DFG). The malacological research of P.S. was supported by the GINOP-2.3.2-15-201600009. We thank to Stevan Savić, Djordjije Vasiljević, Mladjen Jovanović, Biljana Basarin and Nemanja Basarin for their help during the laboratory and fieldwork.

We are very grateful to two anonymous reviewers whose comments and suggestions significantly improved the quality of this study. We especially wish to also extend our deep gratitude to editors Thomas Algeo and Paul Hesse, as well as to guest editor Shiling Yang for their outstanding and detailed comments and suggestions on our manuscript.

\section{Appendix A. Supplementary data}

Supplementary data to this article can be found online at https:// doi.org/10.1016/j.palaeo.2018.03.019.

\section{References}

Antoine, P., Rousseau, D.D., Zöller, L., Lang, A., Munaut, A.V., Hatté, C., Fontugne, M., 2001. High-resolution record of the last inter-glacial glacial cyclein the Nussloch loess palaeosol sequences, Upper Rhine Area, Germany. Quat. Int. 76-77, 211-229. Antoine, P., Rousseau, D.-D., Fuchs, M., Hatté, C., Gauthier, C., Marković, S.B., Jovanović, M., Gaudenyi, T., Moine, O., Rossignol, J., 2009. High-resolution record of the last climatic cycle in the southern Carpathian Basin (Surduk, Vojvodina, Serbia). Quat. Int. 198, 19-36.

Antoine, P., Rousseau, D.D., Degeai, J.P., Moine, O., Lagroix, F., Kreutzer, S., Fuchs, M. Hatté, C., Gauthier, C., Svoboda, J., Lisa, L., 2013. High-resolution record of the environmental response to climatic variations during the Last Interglacial-Glacial cycle in Central Europe: the loess-palaeosol sequence of Dolní Vestonice (Czech Republic). Quat. Sci. Rev. 67, 17-38.

Bjelajac, D., Mesaroš, M., Schaetzl, R.J., Pavić, D., Micić, T., Marković, R.S., Gavrilov, M.B., Perić, Z., Marković, S.B., 2016. Introducing the loess pyramid - an unusual Landformin the thick loess deposits of Vojvodina, Serbia. Geogr. Pannonica 20, 1-7.

Bokhorst, M.P., Beets, C.J., Marković, S.B., Gerasimenko, N.P., Matviishina, Z.N., Frechen, M., 2009. Pedo-chemical climate proxies in Late Pleistocene SerbianUkranian loess sequences. Quat. Int. 198, 113-123.

Bokhorst, M.P., Vandenberghe, J., Sümegi, P., Lanczont, M., Gerasimenko, N.P., Matviishina, Z.N., Marković, S.B., Frechen, M., 2011. Atmospheric circulation patterns in central and eastern Europe during the Weichselian Pleniglacial inferred from loess grain-size records. Quat. Int. 234, 62-74.

Bond, G., Broecker, W., Johnsen, S., McManus, J., Labeyrie, L., Jouzel, J., Bonani, G., 1993. Correlations between climate records from North Atlantic sediments and Greenland ice. Nature 365, 143-147.

Bronger, A., Winter, R., Derevjanko, O., Aldag, S., 1995. Loess-paleosol sequences in Tadjikistan as a paleoclimatic record of the Quaternary in Central Asia. Quat. Proc. 4, 69-81.

Buggle, B., Glaser, B., Zöller, L., Hambach, U., Marković, S., Glaser, I., Gerasimenko, N., 2008. Geochemical characterization and origin of Southeastern and Eastern European loesses (Serbia, Romania, Ukraine). Quat. Sci. Rev. 27, 1058-1075.

Buggle, B., Hambach, U., Glaser, B., Gerasimenko, N., Marković, S.B., Glaser, I., Zöller, L., 2009. Magnetic susceptibility stratigraphy and spatial and temporal paleoclimatic trends in East European loess paleosol sequences. Quat. Int. 196, 86-106.

Buggle, B., Wiesenberg, G.L.B., Glaser, B., 2010. Is there a possibility to correct fossil nalkane data for postsedimentary alteration effects? Appl. Geochem. 25, 947-957.

Buggle, B., Glaser, B., Hambach, U., Gerasimenko, N., Marković, S.B., 2011. An evaluation of geochemical weathering indices in loess-paleosol studies. Quat. Int. 240, $12-21$.

Buggle, B., Hambach, U., Kehl, M., Marković, S.B., Zöller, L., Glaser, B., 2013. The progressive evolution of a continental climate in SE-Central European lowlands during the Middle Pleistocene recorded in loess paleosol sequences. Geology 41, 771-774.

Bush, R.T., McInerney, F.A., 2013. Lead wax $n$-alkane distributions in and across modern plants: implications for paleoecology and chemotaxonomy. Geochim. Cosmochim. Acta $117,161-179$.

Buylaert, J.P., Jain, M., Murray, A.S., Thomsen, K.J., Thiel, C., Sohbati, R., 2012. A robust feldspar luminescence dating method for Middle and Late Pleistocene sediments. Boreas 41, 435-451.

Collins, R.P., Jones, M.B., 1985. The influence of climatic factors on the distribution of C4 species in Europe. Vegetation 64, 121-129.

Dansgaard, W., Johnsen, S.J., Clausen, H.B., Dahl-Jensen, D., Gundestrup, N.S., Hammer, C.U., Hvidberg, C.S., Steffensen, J.P., Sveinbjornsdottir, A.E., Jouzel, J., Bond, G., 1993. Evidence for general instability of past climate from a 250-kyr ice core record. Nature $364,218-220$. 
Diefendorf, A.F., Freeman, K.H., Wing, S.C., Graham, H.V., 2011. Production of $n$-alkyl lipids in living plants and implications for the geologic past. Geochim. Cosmochim. Acta 75, 7472-7485.

Dodd, R.S., Afzal-Rafii, Z., 2000. Habitat-related adaptive properties of plant cuticular lipids. Evolution 54, 1438-1444.

Dodonov, A.E., Baiguzina, L.L., 1995. Loess stratigraphy of Central Asia: paleoclimatic and paleoenvironmental aspects. Quat. Sci. Rev. 14, 707-720.

Evans, M., Heller, F., 2001. Magnetism of loess/palaeosol sequences: recent developments. Earth-Sci. Rev. 54, 129-144.

Feurdean, A., Perşoiu, A., Tantau, I., Stevens, T., Magyari, E.K., Onac, B.P., Marković, S., Andric, M., Connor, S., Farcas, S., Gałka, M., Gaudenyi, T., Hoek, W., Kolaczek, P., Kunes, P., Lamentowicz, M., Marinova, E., Michczynska, D.J., Persoiu, I., Płociennik, M., Słowinski, Stancikaite, M., Sumegi, P., Svensson, A., Tamas, T., Timar, A., Tonkov, S., Toth, M., Veski, S., Willis, K.J., Zernitskaya, V., 2014. Climate variability and associated vegetation response throughout Central and Eastern Europe (CEE) between 60 and 8 ka. Quat. Sci. Rev. 106, 206-224.

Fuchs, M., Rousseau, D.-D., Antoine, P., Hatté, C., Gauthier, C., Marković, S., Zöller, L. 2008. Chronology of the last climatic cycle (Upper Pleistocene) of the Surduk loess sequence, Vojvodina, Serbia. Boreas 37, 66-73.

Gavrilov, N.B., Marković, S.B., Schaetzl, R.J., Tošić, I.A., Zeeden, C., Obreht, I., Sipos, Gy., Ruman, A., Putniković, S., Emunds, K., Perić, Z., Hambach, U., Lehmkuhl, F. Prevailing surface winds in Northern Serbia in the recent and past time periods; modern- and past dust deposition. Aeolian Res., DOI:https://doi.org/10.1016/j. aeolia.2017.07.008 (in press).

Häggi, C., Zech, R., McIntyre, C., Zech, M., Eglinton, T.I., 2014. On the stratigraphic integrity of leaf-wax biomarkers in loess paleosols. Biogeosciences 11, 2455-2463.

Halaváts, Gy, 1895. Az Alföld felszíne. A Magyar Kir. Földtani Intézet Évkönyve XI. 3. pp. 99-173.

Halaváts, Gy, 1897. Az Alföld Duna Tisza közötti részének földtani viszonyai. A Magyar Királyi Földtani Intézet Évkönyve XI. 3. pp. 1-173.

Hapuczi, J., Sümegi, P., 2010. The Late Pleistocene paleoenvironment and paleoclimate of the Madaras section (South Hungary), based on preliminary records from molluscs. Central Eur. J. Geosci. 2, 64-70.

Hatté, C., Gauthier, C., Rousseau, D.D., Antoine, P., Fuchs, M., Lagroix, F., Marković, S.B., Moine, O., Sima, A., 2013. Excursions to C4 vegetation recorded in the Upper Pleistocene loess of Surduk (Northern Serbia): an organic isotope geochemistry study. Clim. Past 9, 1001-1014.

Heinrich, H., 1988. Origin and consequences of cyclic ice rafting in the Northeast Atlantic Ocean during the past 130,000 years. Quat. Res. 29, 142-152.

Heller, F., Evans, M.E., 1995. Loess magnetism. Rev. Geophys. 33, 211-240.

Heller, F., Liu, T., 1984. Magnetism of Chinese loess deposits. Geophys. J. R. Astron. Soc. 77, 125-141.

Hrnjak, I., Lukić, T., Gavrilov, M.B., Marković, S.B., Unkašević, M., Tošić, I., 2014. Aridity in Vojvodina, Serbia. Theor. Appl. Climatol. 115, 323-332.

Jary, Z., 2011. Periglacial markers within the Late Pleistocene loess-palaeosol sequences in Poland and Western Ukraine. Quat. Int. 198, 124-135.

Jouzel, J., Barkov, N.I., Barnola, J.M., Bender, M., Chappelaz, J., Genthon, C., Kotlyakov, V.M., Lipenkov, V., Lorius, C., Petit, J.R., Raynaud, D., Raisbeck, G., Ritz, C., Sowers, T., Stievenard, M., Yiou, F., Yiou, P., 1993. Extending the Vostok ice-core record of paleoclimate to the penultimate glacial period. Nature 364, 407-412.

Konert, M., Vandenberghe, J., 1997. Comparison of laser grain size analysis with pipette and sieve analysis: a solution for the underestimation of the clay fraction. Sedimentology 44, 523-535.

Kostić, N., Protić, N., 2000. Pedology and mineralogy of loess profiles at Kapela-Batajnica and Stalać, Serbia. Catena 41, 217-227.

Krolopp, E., Sümegi, P., 1995. Palaeoecological reconstruction of the late pleistocene,based on loess malacofauna in Hungary. GeoJournal 36, 213-222.

Kukla, G.J., 1987. Loess stratigraphy in central China. Quart. Sci. Rev. 6, 191-219.

Kukla, G., An, Z., 1989. Loess stratigraphy in Central China. Paleogeogr. Palaeoclimatol. Palaeoecol. 72, 203-225.

Liu, X.M., Liu, Z., Lü, B., Marković, S.B., Chen, J.S., Guo, H., Ma, M.M., Zhao, G.Y., Feng, H., 2013. The magnetic properties of Serbian loess and its environmental significance. Chin. Sci. Bull. 58, 353-363.

Ložek, V., 1964. Quärtarmollusken der Tschechoslowakei. Rozpravy Ústredniho ústavu geologického. 31. pp. 3-374 (Praha).

Ložek, V., 1969. Le loess et les formations assimilees: correlation entre l'Europe centrale et la France par la faune de mollusques. In: Etudes sur le Quaternaire dans le monde. VIII Congres INQUA Paris, pp. 597-606.

Machalett, B., Oches, E.A., Frechen, M., Zöller, L., Hambach, U., Mavlyanova, N.G., Marković, S.B., Endlicher, W., 2008. Aeolian dust dynamics in Central Asia during the Pleistocene - driven by the long-term migration, seasonality and permanency of the Asiatic polar front. Geophys. Geochem. Geosyst. 9, Q08Q09. http://dx.doi.org/10. 1029/2007GC001938.

Maffei, M., Badino, S., Bossi, S., 2004. Chemotaxonomic significance of leaf wax $n$-alkanes in the Pinales (Coniferales). J. Biol. Res. 1, 3-19.

Marković, S.B., Kostić, N.S., Oches, E.A., 2004. Paleosols in the Ruma loess section (Vojvodina, Serbia). Rev. Mex. Cienc. Geol. 21, 79-87.

Marković, S.B., McCoy, W.D., Oches, E.A., Savić, S., Gaudenyi, T., Jovanović, M., Stevens, T., Walther, R., Ivanišević, P., Galić, Z., 2005. Paleoclimate record in the Late Pleistocene loess-palaeosol sequence at Petrovaradin Brickyard (Vojvodina, Serbia). Geol. Carpath. 56, 483-491.

Marković, S.B., Oches, E., Sümegi, P., Jovanović, M., Gaudenyi, T., 2006. An introduction to the Upper and Middle Pleistocene loess-palaeosol sequences of Ruma section (Vojvodina, Yugoslavia). Quat. Int. 149, 80-86.

Marković, S.B., Oches, E.A., McCoy, W.D., Gaudenyi, T., Frechen, M., 2007. Malacological and sedimentological evidence for "warm" climate from the Irig loess sequence
(Vojvodina, Serbia). Geophys. Geochem. Geosyst. 8, Q09008. http://dx.doi.org/10. 1029/2006GC001565.

Marković, S.B., Bokhorst, M., Vandenberghe, J., Oches, E.A., Zöller, L., McCoy, W.D., Gaudenyi, T., Jovanović, M., Hambach, U., Machalett, B., 2008. Late Pleistocene loess-palaeosol sequences in the Vojvodina region, North Serbia. J. Quat. Sci. 23, 73-84.

Marković, S.B., Hambach, U., Catto, N., Jovanović, M., Buggle, B., Machalett, B., Zöller, L., Glaser, B., Frechen, M., 2009. Middle and Late Pleistocene loess sequences at Batajnica, Vojvodina, Serbia. Quat. Int. 198, 255-266.

Marković, S.B., Hambach, U., Stevens, T., Kukla, G.J., Heller, F., McCoy, W.D., Oches, E.A., Zöller, L., 2011. The last million years recorded at the Stari Slankamen (Northern Serbia) loess-palaeosol sequence: revised chronostratigraphy and longterm environmental trends. Quat. Sci. Rev. 30, 1142-1154.

Marković, S.B., Hambach, U., Jovanović, M., Stevens, T., O'Hara-Dhand, K., Basarin, B., Smalley, I.J., Buggle, B., Zech, M., Svirčev, Z., Milojković, N., Zöller, L., 2012. Loess in Vojvodina region (Northern Serbia): the missing link between European and Asian Pleistocene environments. Neth. J. Geosci. 91, 173-188.

Marković, S.B., Timar-Gabor, A., Stevens, T., Hambach, U., Popov, D., Tomić, N., Obreht, I., Jovanović, M., Lehmkuhl, F., Kels, H., Marković, R., Gavrilov, M.B., 2014a. Environmental dynamics and luminescence chronology from the Orlovat loess-palaeosol sequence (Vojvodina, Northern Serbia). J. Quat. Sci. 29, 189-199.

Marković, S.B., Korać, M., Mrđić, N., Buylaert, J.P., Thiel, C., McLaren, S.J., Stevens, T., Tomić, N., Petić, N., Jovanović, M., Vasiljević, Dj.A., Sümegi, P., Gavrilov, M.B., Obreht, I., 2014b. Palaeoenvironment and geoconservation of mammoths from the Nosak loess-palaeosol sequence (Drmno, northeastern Serbia): initial results and perspectives. Quat. Int. 334-335, 30-39.

Marković, S.B., Stevens, T., Kukla, G.J., Hambach, U., Fitzsimmons, K.E., Gibbard, P., Buggle, B., Zech, M., Guo, Z.T., Hao, Q.Z., Wu, H., O'Hara-Dhand, K., Smalley, I.J., Ujvari, G., Sümegi, P., Timar-Gabor, A., Veres, D., Sirocko, F., Vasiljević, Dj.A., Jari, Z., Svensson, A., Jović, V., Kovács, J., Svirčev, Z., 2015. The Danube loess stratigraphy - new steps towards the development of a pan-European loess stratigraphic model. Earth-Sci. Rev. 148, 228-258.

Marković-Marjanović, J., 1964. Geomorfologija i stratygrafija czwatrozendu miedzyrzecza Dunaj-Cisa w Jugoslawii. Cz. I Annales UMSC, Sec. B. 19/2. pp. 1-28.

Marković-Marjanović, J., 1966. Geomorfologija i stratygrafija czwatrozendu miedzyrzecza Dunaj-Cisa w Jugoslawii. Cz. II Annales UMSC, Sec. B. 21/2. pp. 27-56.

Marković-Marjanović, J., 1967. Geomorfologija I stratygrafija czwatrozendu miedzyrzecza Dunaj-Cisa w Jugoslawii. Cz. III Annales UMSC, Sec. B. 22/3. pp. 59-76.

Miller, B.A., Schaetzl, R.J., 2012. Precision of soil particle size analysis using laser diffractometry. Soil Sci. Soc. Am. J. 76, 1719-1727.

Molnár, B., Krolopp, E., 1978. Latest Pleistocene geohistory of the Bácska Loess Area. Acta Mineral. Petrogr. 23, 245-264.

Molnár, A., Sümegi, P., 1990. Classification and ordination methods in the division of the Pleistocene malacological zones of Debrecen I profile. Soosiana 18, 11-16.

Molnár, D., Hapuczi, J., Galović, L., Sümegi, P., 2010. Preliminary malacological investigation of the loess profile at Zmajevac, Croatia. Central Eur. J. Geosci. 2, 52-56.

Murray, A.S., Schmidt, E.D., Stevens, T., Buylaert, J.P., Marković, S.B., Tsukamoto, S., Frechen, M., 2014. Dating Middle Pleistocene loess from Stari Slankamen (Vojvodina, Serbia) - limitations imposed by the saturation behaviour of an elevated temperature IRSL signal. Catena 117, 34-42.

Obreht, I., Buggle, B., Catto, N., Marković, S.B., Bösel, S., Vandenberghe, D.A.G., Hambach, U., Svirčev, Z., Lehmkuhl, F., Basarin, B., Gavrilov, M.B., Jović, G., 2014 The Late Pleistocene Belotinac section (southern Serbia) at the southern limit of the European loess belt: environmental and climate reconstruction using grain size and stable C and N isotopes. Quat. Int. 234-235, 10-19.

Obreht, I., Zeeden, C., Hambach, U., Veres, D., Marković, S.B., Bösken, J., Svirčev, Z., Bačević, N., Gavrilov, M.B., Lehmkuhl, F., 2016. Tracing the influence of Mediterranean climate on Southeastern Europe during the past 350,000 years. Sci. Rep. 6, 36334.

Obreht, I., Hambach, U., Veres, D., Zeeden, C., Bösken, J., Stevens, T., Marković, S.B., Klasen, N., Brill, D., Burow, C., Lehmkuhl, F., 2017. Shift of large-scale atmospheric systems over Europe during late MIS 3 and implications for Modern Human dispersal. Sci. Rep. 7, 5848 .

Perić, Z., Lagerbäck Adophi, E., Buylaert, J.P., Stevens, T., Újvári, G., Marković, S.B., Hambach, U., Fischer, P., Zeeden, C., Schmidt, C., Schulte, P., Lu, H., Yi, S., Lehmkuhl, F., Obreht, I., Veres, D., Thiel, C., Frechen, M., Jain, M., Vött, A., Zöller, L., Gavrilov, M.B. Quartz OSL dating of late Quaternary Chinese and Serbian loess: a cross Eurasian comparison of dating results and mass accumulation rates. Quat. Int. DOI: https://doi.org/10.1016/j.quaint.2018.01.010 (in press).

Porter, S., 2001. Chinese loess record of monsoon climate during the last glacial-inter glacial cycle. Earth-Sci. Rev. 54, 115-128.

Roberts, H.M., 2008. The development and application of luminescence dating to loess deposits: a perspective on the past, present and future. Boreas 37, 483-507.

Rousseau, D.D., 2001. Loess biostratigraphy e new advances and approaches in mollusk studies. Earth-Sci. Rev. 54, 151-171.

Rousseau, D.D., Sima, A., Antoine, P., Hatté, C., Lang, A., Zöller, L., 2007. Link between European and North-Atlantic abrupt climate changes over the Last Glaciation. Geophys. Res. Lett. 34, L22713. http://dx.doi.org/10.1029/2007GL031716.

Rudner, E., Sümegi, P., 2001. Recurring taiga forest steppe habitats in the Carpathian Basin in the Upper Weichselian. Quat. Int. 76 (77), 177-189.

Schäfer, I., Lanny, V., Franke, J., Eglinton, T., Zech, M., Vysloužilová, B., Zech, R., 2016. Leaf waxes in litter and topsoils along a European transect. Soil Discuss. http://dx. doi.org/10.5194/soil-2016-37.

Schatz, A., Zech, M., Buggle, B., Gulyas, S., Hambach, U., Markovic, S., Sümegi, P., Scholten, T., 2011. The late Quaternary loess record of Tokaj, Hungary: reconstructing palaeoenvironment, vegetation and climate using stable $\mathrm{C}$ and $\mathrm{N}$ 
isotopes and biomarkers. Quat. Int. 240, 52-61.

Schmidt, E.D., Machalett, B., Marković, S.B., Tsukamoto, S., Frechen, M., 2010. Luminescence chronology of the upper part of the Stari Slankamen loess sequence (Vojvodina, Serbia). Quat. Geochronol. 5, 137-142.

Schreuder, L.T., Beets, C.J., Prins, M.A., Hatté, C., Peterse, F., 2016. Late Pleistocene climate evolution in Southeastern Europe recorded by soil bacterial membrane lipids in Serbian loess. Palaeogeogr. Palaeoclimatol. Palaeoecol. 449, 141-148.

Seelos, K., Sirocko, F., Dietrich, S., 2009. A continuous high-resolution dust record for the reconstruction of wind systems in central Europe (Eifel, Western Germany) over the past 133 ka. Geophys. Res. Lett. 36.

Singer, M.J., Verosub, K.L., 2007. Paleosol and wind-blown sediments - mineral magnetic analysis. Encycl. Quat. Sci. 2096-2102.

Sirocko, F., Knapp, H., Dreher, F., Förster, M.W., Albert, J., Brunck, H., Veres, D. Dietrich, S., Zech, M., Hambach, U., Röhner, M., Rudert, S., Schwibus, K., Adams, C., Sigl, P., 2016. The ELSA-vegetation-stack: reconstruction of landscape evolution zones (LEZ) from laminated Eifel maar sediments of the last 60,000 years. Glob. Planet. Chang. 142, 108-135.

Smalley, I.J., Marković, S.B., Svirčev, Z., 2011. Loess is [almost totally formed by] the accumulation of dust. Quat. Int. 240, 4-11.

Stevens, T., Armitage, D.S.G., Lunn, H.R., Lu, H., 2007. Reinterpreting climate proxy records from late Quaternary Chinese loess: a detailed OSL investigation. Earth-Sci. Rev. 80, 111-136.

Stevens, T., Marković, S.B., Zech, M., Sümegi, P., 2011. Dust deposition and climate in the Carpathian Basin over an independently dated last glacial-interglacial cycle. Quat. Sci. Rev. 30, 662-681.

Sümegi, P., 1989. The Upper Pleistocene Geohistory of the Hajdúság Region Based on Fine-stratigraphical (Palaeontological, Sedimentological, Geochemical) Analyses (University Doctoral thesis). 96 Kossuth University, Debrecen (in Hungarian).

Sümegi, P., 2005. Loess and Upper Paleolithic environment in Hungary. Aurea Kiadó, Nagykovácsi 312

Sümegi, P., Krolopp, E., 1995. Palaeoecological reconstruction of the Hungarian Weichselian loess development. Földtani Közlony 124, 124-148 (in Hungarian with English abstract).

Sümegi, P., Krolopp, E., 2002. Quatermalacological analyses modelling of the Upper Weichselian palaeoenviromental changes in the Carpathian Basin. Quat. Int. 91, 53-63.

Sümegi, P., Szilágyi, G., 2010. A Hortobágy új felszínfejlődési modellje és a szikesedés eredete. Acta Biol. Debrecin 22, 27-36.

Sümegi, P., Szilágyi, G., 2011. A quarter-malacological inventory of Hungarian kurgans. In: Petô, Á., Barczi, A. (Eds.), Kurgan Studies: An Environmental and Archaeological Multiproxy Study of Burial Mounds in the Eurasian Steppe Zone. 2238. British Archaeological Reports, Oxford, pp. 279-291.

Sümegi, P., Gulyás, S., Csökmei, B., Molnár, D., Hambach, U., Stevens, T., Markovic, S.B., Almond, P.C., 2013. Climatic fluctuations inferred for the Middle and Late
Pleniglacial (MIS 2 ) based on high-resolution ( $\sim$ ca. 20 y) preliminary environmental magnetic investigation of the loess section of the Madaras brickyard (Hungary). Cent. Eur. Geol. 55, 329-345.

Sümegi, P., Marković, S., Molnár, D., Sávai, S., Náfrádi, K., Szelepcsénzi, Z., Novák, Z., 2016. Crvenka loess-paleosol sequence revisited: local and regional Quaternary biogeographical inferences of the southern Carpathian Basin. Open Geosci. 8, $390-404$.

Tarasov, P.E., Müller, S., Zech, M., Andreeva, D., Diekmann, B., Leipe, C., 2013. Last glacial vegetation reconstructions in the extreme-continental eastern Asia: potentials of pollen and $n$-alkane biomarker analyses. Quat. Int. 290-291, 253-263.

Thiel, C., Buylaert, J.P., Murray, A.S., Terhorst, B., Hofer, I., Tsukamoto, S., Frechen, M., 2011. Luminescence dating of the Stratzing loess profile (Austria) - testing the potential of an elevated temperature post-IR IRSL protocol. Quat. Int. 234, 23-31.

Tzedakis, P.C., Hooghiemstra, H., Pälike, H., 2006. The last 1.35 million years at Tenaghi Philippon: revised chronostratigraphy and long-term vegetation trends. Quat. Sci. Rev. 25, 3416-3430.

Újvári, G., Kovács, J., Varga, G., Raucsik, B., Marković, S.B., 2010. Dust flux estimates for the Last Glacial Period in East Central Europe based on terrestrial records of loess deposits: a review. Quat. Sci. Rev. 29, 3157-3166.

Vandenberghe, J., 2013. Grain size of fine-grained windblown sediment: a powerful proxy for process identification. Earth Sci. Rev. 121, 18-30.

Vandenberghe, J., Marković, S.B., Jovanović, M., Hambach, U., 2014. Site-specific variability of loess and palaeosols (Ruma, Vojvodina, northern Serbia). Quat. Int. 234 (235), 86-93.

Willis, K.J., Rudner, E., Sümegi, P., 2000. The full-glacial forests of central and southeastern Europe. Quat. Res. 53, 203-213.

Wohlfarth, B., Veres, D., Ampel, L., Lacourse, T., Blaauw, M., Preusser, F., Andrieu-Ponel, V., Kéravis, D., Lallier-Vergès, E., Björck, S., Davies, S.M., de Beaulieu, J.-L., Risberg, J., Hormes, A., Kasper, H.U., Possnert, G., Reille, M., Thouveny, N., Zander, A., 2008. Rapid ecosystem response to abrupt climate changes during the last glacial period in western Europe, 40-16 ka. Geology 36, 407-410.

Zech, M., Buggle, B., Leiber, K., Marković, S., Glaser, B., Hambach, U., Huwe, B., Stevens, T., Sümegi, P., Wiesenberg, G., Zöller, L., 2009. Reconstructing Quaternary vegetation history in the Carpathian Basin, SE Europe, using n-alkane biomarkers as molecular fossils: problems and possible solutions, potential and limitations. Eiszeitalter und Gegenwart. Quat. Sci. J. 58, 148-155.

Zech, M., Rass, S., Buggle, B., Löscher, M., Zöller, L., 2012. Reconstruction of the late Quaternary paleoenvironments of the Nussloch loess paleosol sequence, Germany, using n-alkane biomarkers. Quat. Res. 78, 226-235.

Zech, R., Zech, M., Marković, S.B., Hambach, U., Huang, Y., 2013. Humid glacials, arid interglacials? Critical thoughts on pedogenesis and paleoclimate based on multiproxy analyses of the loess-paleosol sequence Crvenka, Northern Serbia. Palaeogeogr. Palaeoclimatol. Palaeoecol. 387, 165-175. 